\title{
Language and Style in Mamluk Historiography
}

\author{
Koby Yosef
}

The increasing use of nonstandard Arabic by Mamluk historians in the historical narrative (hawādith) of chronicles has been considered as one of the most noticeable characteristics of the process of "literarization," or the popularization of Mamluk historiography, ${ }^{1}$ which went hand in hand with the increasing use of stylistic elements drawn from the literature of adab, perhaps most notably anecdotes or story-like reports with dialogues or utterances in direct speech. ${ }^{2}$

While some, mainly editors of Mamluk historical works, made notes and observations on the language of specific works or historians, to date, there have not been too many attempts at an overall survey of different general trends of language use in Mamluk historical texts. Notwithstanding this, it has been suggested that usages of nonstandard Arabic are more typical of the 9 th $/ 15^{\text {th }}$ century, ${ }^{3}$ and more specifically of Egypt in the second half of the 9 th $/ 15^{\text {th }}$ century (the so-called "Cairo narrative style"). ${ }^{4}$ This chronological/geographical perspective, however, downplays the facts that many Mamluk historians used nonstandard Arabic before the 9th/15th century and that some Syrian historians also used nonstandard Arabic.

Alternatively, it has been suggested that differences in background and life experience of the historians affected their language and style. Ulrich Haarmann perhaps did not state explicitly that usages of nonstandard Arabic are typical of historians related to the military institution; however, he highlighted the fact that many of the historians who wrote "literarized" histories employ-

* I would like to thank my friend and colleague Almog Kasher for reading a draft of this paper and making some very useful comments on issues relating to Arabic grammar.

1 See, for example, Haarmann, Quellenstudien 175-6; Auflösung 56; Review of Weltgeschichte 134-5; Guo, Introduction 94; Parry, Review 148; Mauder, Gelehrte 24.

2 See, for example, Haarmann, Quellenstudien 178-9; and see also Guo, Introduction 95-6; Little, Historiography 420.

3 See most recently, Elbendary, Crowds 82.

4 Ibn al-Ṣayrafî, Inbä' 17-21 (esp. 20); Petry, Protectors 6. And see in detail in section 5 below. 
ing nonstandard Arabic were soldiers ${ }^{5}$ and labeled as "conservative" several historians who were religious scholars. ${ }^{6}$ Donald Little noted that the lack of rigorous academic training of "historians closely associated with the Mamluk military institution either as fully-fledged soldiers or as sons of Mamluks" is betrayed by their Arabic prose, which is "permeated with colloquialisms." Frédéric Bauden noted that in contrast to historians related to the military institution who did not hesitate to include nonstandard usages of Arabic in their historical works, religious scholars who wrote history were very careful not to allow themselves such deviations from standard Arabic. ${ }^{8}$ In what is probably the most elaborate discussion of language and style in Mamluk historiography examining "Mamluk historians as groups ... who were associated with particular settings ... or who shared ideological and professional bonds,"9 Li Guo noted that differences in career paths and social, ethnic, cultural, and intellectual backgrounds of historians must have had some influence on the language and style of their writings. ${ }^{10}$ Like other scholars, Guo noted that the tendency to use nonstandard Arabic characterizes historians related to the military institution, particularly those of non-Arab origin. ${ }^{11}$ This social/cultural/professional perspective, however, downplays the fact that some religious scholars who wrote historical works were employing nonstandard usages of Arabic. This is not to say that the latter were totally ignored. Haarmann was, of course, well-aware that the Syrian religious scholar al-Jazarī (d. 739/1338) incorporated adab-like elements and nonstandard Arabic in his chronicle; however, he highlighted the fact that this trend was best exemplified in the chronicle of Ibn al-Dawādārī (d. after 736/1335), the Egyptian historian who was a mamlük's descendant. ${ }^{12}$ Guo noted that not only al-Jazarī but also the Syrian religious scholar al-Yūnīnī (d. 726/1326) was incorporating anecdotes, stories, and nonstandard usages of Arabic in his chronicle; ${ }^{13}$ however, he concluded that "the introduction of entertaining stories in a ta'rikh work and the use of colloquial language in its narrative were, to be sure, still

\footnotetext{
$5 \quad$ Haarmann, Auflösung 59; and see also Mauder, Gelehrte 25.

6 Haarmann, Auflösung 54 .

7 Little, Historiography 420.

8 Bauden, Maqriziana viII $36-7$.

9 Guo, Mamluk 29.

$10 \quad$ Ibid. 29-32; and see also ibid. 41-3.

11 Ibid. 30, 43.

12 Haarmann, Quellenstudien 176-9; Auflösung 55; Review of Weltgeschichte 134-5; Parry, Review 148; and see also Guo, Introduction 96.

13 Guo, Introduction 94-5.
} 
far from being fully developed in al-Yūnīnìs and al-Jazarī's works, compared to later Egyptian chronicles ... such as those of Ibn al-Dawādārī ... wherein such a 'literarized' trend ... appears to be quite overwhelming."14 Guo emphasized the dissimilarities between the trends of "literarization" in the chronicles of historians related to the military institution and those who were religious scholars. Whereas the trend in Ibn al-Dawādārī and historians related to the military institution is typified by the incorporation of elements of adab "in its 'lower' form" (perhaps most notably anecdotes, stories, and nonstandard Arabic) in the historical narrative, the trend in al-Yūnīnī and al-Jazarì is typified by the incorporation of "high adab elements" (mainly poetry in a classical form) in the obituaries (wafayāt). ${ }^{15}$ According to Guo, it is thus not surprising to see in the works of the latter a struggle "with regard to language and style."16

Some have made a connection between the different backgrounds of historians, which affected their language and style, and their different geographical settings. As noted by Guo, who focused on the Turkish period of the Mamluk Sultanate $\left(648-784 / 125^{\circ}-1382\right)$, practically all chroniclers related to the military institution were Egyptian, whereas practically all Syrian chroniclers were religious scholars. In fact, during the Turkish period "none of the major Egyptian chronicles" were written by religious scholars. ${ }^{17}$ Thus, "it is undeniable that there are certain traits that ought to be seen as characterizing Mamluk Egyptian authors." ${ }^{18}$ This combined perspective, however, downplays the fact that during the Circassian period of the sultanate (784-923/1382-1517), many Egyptian historians were religious scholars.

So, to date, there is no general survey of trends of language use that covers all major historians throughout the Mamluk period. In addition, to date, it has not been properly explained why some Mamluk historians who were religious scholars were willing to employ nonstandard usages of Arabic while others refrained from doing so. In what follows I will offer such a survey and suggest that in order to better understand trends of language use in Mamluk historiography, a further differentiation should be made between subgroups of historians who were religious scholars.

In order to check in detail usages of Arabic, it is necessary, of course, to consult manuscripts and autographs when they exist; however, it is better to

\footnotetext{
14 Ibid. 96.

15 Guo, Mamluk 39; Introduction 96.

16 Ibid., Introduction 96.

17 Ibid., Mamluk 29-32.

18 Ibid. 41 .
} 
emphasize in advance this is not the intention here. The intention is to survey general trends of usages of nonstandard Arabic and standardization thereof. Using the existing printed editions (some based on autographs) and relying on observations mainly made by editors of Mamluk historical works (some based on autographs) should allow a preliminary survey of such general trends (standardization by copyists and the occasional standardizing of a text by the editor without indication should be considered).

Appendix A includes a survey of observations regarding usages of Arabic in the works of Mamluk historians, mainly in chronicles but also in biographical dictionaries. As mentioned, the observations were often made by editors of historiographical texts, some of which are based on autographs (this fact is indicated in the appendix). To these observations, I have added my own observations, which are based on printed editions, some, again, are based on autographs (this is also indicated in the appendix). My observations also include cases of standardization made by some Mamluk historians of nonstandard usages employed in earlier historical works that were incorporated into their own works.

I have divided the appendix into five groups of historians. The first group (group A) is historians related to the military institution (mamlüks and soldiers, and descendants of mamlüks). The four other groups are historians of civilian background, that is, religious scholars related to three schools of law, the Hanafì, Hẹanbalī, and Shāfíi (groups B, C, and E), and udab $\bar{a}^{\prime}-k u t t a ̄ b$ (group D). It will be shown that usages of nonstandard Arabic are typical of historians related to the military institution (section 2 below) and non-Shāfici religious scholars (section 3 below). On the other hand, Shāfi'i religious scholars refrained from using nonstandard Arabic (section 4 below) because of the importance of "Arabness" and the Arabic language in their ethos (section 4.2 below). The trends of language use will be examined in tandem with one stylistic element - the incorporation of story-like reports with dialogues and direct speech in accounts of contemporary events ${ }^{19}$ in the historical narrative in chronicles. This will allow a more nuanced differentiation between trends of language use and style prevalent among chroniclers of the three aforementioned major groups of historians: those related to the military institution, non-Shāfi'ì religious scholars, and Shāfīì religious scholars (section 5 below). Finally, the survey will allow a reevaluation of Nasser Rabbat's observation that conversations between mamlūks are reported in colloquial Arabic

19 By that I mean historians' reports on their own time and not reports on past events taken from earlier sources. 
as part of a deliberate negative representation of the mamlūks by Mamluk historians (section 6 below). It will also allow some general observations concerning language and style in works pertaining to history that were written by $u d a b \bar{a}^{\prime}-k u t t \bar{a} b$ and language use in biographical dictionaries (section 6.1 below).

\section{2 \\ Historians Related to the Military Institution (Mamlūks and Soldiers, and Descendants of Mamlūks)}

There should be no doubt that almost all historians related to the military institution (group A in appendix A) allowed themselves to employ usages of nonstandard Arabic in a significant manner when describing contemporary events. ${ }^{20}$ In fact, the only historian in this category that did not employ nonstandard Arabic (at least not in any significant manner) is Baybars al-Manșūrī (d. 725/1325), who, as a dawādār and chief of the chancery, was related to the insh $\bar{a}$ ' tradition, which favors ornamented language, poetry, and rhymed prose in impeccable Arabic. ${ }^{21}$ The nonstandard usages in the writings of members of this group appear in quoted dialogues or utterances in direct speech (mainly in the frame of story-like reports), as well as in the narrative line itself. Of course, some were more inclined toward such usages and some less. Roughly (and in an impressionistic manner) it is possible to divide the members of this group into three subgroups:

1. Al-Yūsufī (d. 759/1358) and Ibn al-Dawādārī, whose chronicles contain an abundance of story-like reports with dialogues in the description of contemporary events (in al-Yūsufî's chronicle it is hard to find what may be called a formal informative narrative line), are also, as a result, the most inclined to employ nonstandard Arabic, quantitatively and qualitatively.

2. Qarațāy (d. after 708/1308), Baktāsh al-Fākhirī (d. 745/1344), al-Shujāī (d. after 756/1356), Ibn Duqmāq (d. 8o9/1407), al-Malațī (d. 920/1514), and Ibn Iyās (d. ca. 930/1524) employ nonstandard usages extensively in the formal informative narrative line. Their chronicles, however, contain less story-like reports with dialogues or direct speech than the chronicles of

20 See appendix A group A.

21 See appendix A group A (exception); and see Haarmann, Quellenstudien 179; Irwin, Mamluk history 163; Little, Historiography 423-4. On the insh $\vec{a}^{3}$ tradition, see chapter 1 , footnote 14 (3). 
al-Yūsufî and Ibn al-Dawādārī. ${ }^{22}$ As a result, it would seem that nonstandard usages in their writing are more restricted (especially qualitatively).

3. Ibn Taghrībirdī (d. 874/1470) restricts nonstandard usages mainly to dialogues or utterances in direct speech in story-like reports.

It may be added that it would seem that Ibn Taghrībirdī and Ibn al-Dawādārī were less inclined to employ nonstandard usages of Arabic in the formal narrative line, ${ }^{23}$ and Qaratāay was possibly less inclined to employ nonstandard usages of Arabic in quoted dialogues. ${ }^{24}$

Historians Who Were Religious Scholars: Ḥanbalīs and Ḥanafīs

Among the historians related to Hanbalī circles (group C in appendix A), it is clear that al-Yūnīnī and al-Jazarī were willing to employ nonstandard usages of Arabic in a significant manner when describing contemporary events, ${ }^{25}$ whether in dialogue quotations in the frame of story-like reports or in the more formal narrative line. ${ }^{26}$ As for al-Birzālī (d. 739/1339), his chronicle is almost totally "deliterarized" and contains almost no story-like reports. This perhaps

22 The chronicles of al-Shujāì and Qarațāy seem to contain more dialogues or utterances in direct speech than the chronicles of Ibn Iyās and Ibn Duqmāq, which, in their turn, seem to contain more dialogues or direct speech than the chronicle of al-Malatīi. The chronicle of Baktāsh al-Fākhirī does not seem to contain many dialogues or utterances in direct speech.

23 On Ibn Taghrībirdī, see appendix A group A (mamlūks' descendants no. 3-footnote 178). On a vernacular poem incorporated in a story-like report, see Guo, Songs 189-9o. As for Ibn al-Dawādārī, in comparison to members of subgroup 2 it would seem that he was less inclined to employ nonstandard Arabic in the more formal informative narrative line; see also Haarmann, Quellenstudien 177-8. In contrast to Ibn Taghrībirdī, however, he seems to be more inclined to employ nonstandard Arabic in story-like reports also outside of dialogues; see, for example, Ibn al-Dawādārī, Kanz ix, 195-204 (195-7: informative accounts that are relatively clean of nonstandard usages. 198-204: a story-like report about the arrest of an amir which includes many dialogues with nonstandard usages of Arabic; however, some nonstandard usages are found outside the dialogues. See especially 200 line 15 - colloquial usages in dialogue [ $b$ - imperfect], line 17-annahum yabītū [standard, yabitüna] not in the dialogue but still in the frame of the story-like report); and see also ibid. ix, 210-6 (210-1: informative accounts in the beginning of the year $711 / 1311-2$ that are relatively clean of nonstandard usages. 212-6: a story-like report with dialogues employing many nonstandard usages, mainly in dialogues but at times not [see 216 line 4-a double usage of the $b$-imperfect not in the frame of a dialogue]).

24 Haarmann, Quellenstudien 179; Irwin, Mamluk History 164-5; and see appendix A group A (mamlüks no. 1-footnote 168).

25 See appendix A group C nos. 1-2.

26 Guo, Introduction 95. 
partially accounts for the fact that there are hardly any usages of nonstandard Arabic in his chronicle. There is evidence, however, that he perhaps did not object to such usages in principle. In the rare cases in which his chronicle does contain story-like reports, we find within the reports some usages of nonstandard Arabic. ${ }^{27}$

As for historians who were Hanafì religious scholars (group B in appendix A), it is clear that Ibn al-Furāt (d. 807/1405) and Ibn al-Ṣayrafĩ (d. 9oo/1495) were willing to employ nonstandard usages of Arabic extensively when describing contemporary events, whether in dialogue quotations or in the more formal narrative line. ${ }^{28}$ In accounts of his own time, Ibn al-Furāt's chronicle Ta'rïkh al-duwal wa-l-mulük is full of usages of nonstandard Arabic. However, these accounts generally do not contain many story-like reports with dialogues or utterances in direct speech; thus, the usages of nonstandard Arabic are mainly found in the narrative line. ${ }^{29}$ This seems to be the case also with Inbä al-hașr bi$a b n \bar{a}^{3} a l-$ ' $a s ̦ r$, Ibn al-Șayrafi's chronicle dedicated to his own time. However, Ibn al-Ṣayrafì apparently incorporated a few more story-like reports with dialogues or utterances in direct speech than Ibn al-Furāt did..$^{30}$ Typically, the nonstandard usages in the narrative line of Ibn al-Furāt's and Ibn al-Ṣayrafís chronicles are related to morphology or morphosyntax (i.e., case endings, mood endings, concord, genetive constructs, etc.) and not to vocabulary (words or expressions drawing on colloquial language).

As for Ibn Ṭūlūn (d. 953/1546), it is clear that he allowed himself to employ some nonstandard usages of Arabic in his chronicle Mufäkahat al-khillān $f \imath$ hawädith al-zamān. ${ }^{31}$ Richard Hartmann concluded that "vulgar forms" are not uncommon in the autograph manuscript of a fragment of Mufākahat alkhillān and mentioned that, because of that, Ibn Țūlūn was criticized by his contemporaries. Except for orthography- or numeral-related usages, Hartmann mentioned that the absence of the accusative alif is very common and added that many of the usages described by Zetterstéen in the introduction to his Beiträge zur Geschichte der Mamlükensultane are occasionally also found in Mufākahat al-khillān. ${ }^{32}$ It would seem, however, that Ibn Țūlūn incorporated,

27 See appendix A group C (exception: footnote 200); and see chapter 1 footnote 12.

28 See appendix A group B nos. 1, 3 .

29 See chapter 1 at footnotes $48,54$.

30 For examples of story-like reports with dialogues (some containing usages of nonstandard Arabic), see Ibn al-Ṣayrafî, Inb $\vec{a}^{\prime} 34$ (especially at footnote 3), 130, 141-2, 146, 154-5. Note that normally, the editor of Inb $\vec{a}^{3}$ al-hașr gives standardized versions in the body of the text and mentions the original nonstandard wording only in footnotes.

31 See appendix A group B no. 4.

32 Hartmann, Tübinger $103-4$ (esp. 103 footnote 2). 
in his chronicle, nonstandard usages of Arabic in a less conspicuous manner than the aforementioned Ḥanafì historians. Muhammad Mușțafā, who edited the autograph manuscript examined by Hartmann, noted that the language of Ibn Ṭūūn in Mufākahat al-khillān is in general standard (salīm al-ibāra bi-șifa 'āmma), but sometimes colloquial expressions (ta'bìrāt 'āmmiyya/muștalahăt Dimashqiyya așila) infiltrate his text. ${ }^{33}$ Indeed, in Muștafā's edition of Mufākahat al-khillān, nonstandard usages related to morphology or morphosyntax in the narrative line are not as numerous as in the chronicles of Ibn al-Furāt and Ibn al-Ṣayrafi. ${ }^{34}$ On the other hand, in comparison with the chronicles of Ibn al-Furāt and Ibn al-Ṣayrafî, expressions that seem to draw on colloquial vocabulary are more common in the narrative line. ${ }^{35}$ Indeed, except for Hartmann,

33 Ibn Ṭūlūn, Mufākahat, ed. M. Mușțafā ii, 2o; and see also İbish, Tảrīkh 73.

34 This is not to say that they are rare: 1) For the absence of the accusative alif, see, for example, Ibn Țūlūn, Mufākahat, ed. M. Mușțafā i, 6 (see the editor's note in line 5). On the phenomenon in Middle Arabic, see Blau, Handbook 44 (no. 74); on the phenomenon in Mamluk historiographical texts, see Haarmann, Kanz 37; Zetterstéen, Beiträge 20. 2) For active participles of tertiae $y \bar{a}$ ' verbs appearing with a final $y \bar{a}$ ' in indefinite forms of the nominative/genitive, see Ibn Țūlūn, Mufākahat, ed. M. Muștafāa i, 7 (editor's note in line 21). On this phenomenon in Middle Arabic, see Blau, Handbook 41 (no. 57); in Mamluk historiographical texts, see Brinner, Chronicle, xxiv. 3) For the $-n$ of the sound masculine plural ending preserved in the construct, see Ibn Țūlūn, Mufākahat, ed. M. Muștafā i, 13 (editor's note in line 9), 31 (editor's note in line 8). On the phenomenon in Middle Arabic see Blau, Handbook 42 (no. 61); in Mamluk historiographical texts, see Zetterstéen, Beiträge 21. 4) Imperfect forms in all moods may terminate with and without the ending $n$, see Ibn Ṭūlūn, Mufākahat, ed. M. Mușțafāi i, 29 (editor's note in line 12), 31 (line 11). On the phenomenon in Middle Arabic, see Blau, Handbook 45 (no. 77). Such usages are found (perhaps somewhat more often) also in the narrative line in Ilām al-warā. For the absence of the accusative alif, see Ibn Ṭūlūn, I'lām 111 (line 14-as a khabar kāna, the adjectives khafîf, thaqül, qarīb, and baìd appear without accusative alif), 113 (line 6-as a direct object, the noun māl appears without accusative alif). For sound masculine plurals in the obliquus instead of the casus rectus, see ibid. 108 (line 5-mukhtalifina instead of mukhtalifüna). On the phenomenon in Middle Arabic, see Blau, Handbook 44 (no. 74); in Mamluk historiographical texts, see Zetterstéen, Beiträge 21; Haarmann, Kanz 36. On the other hand, one finds nouns in the nominative when in standard Arabic they should have been in the accusative, see Ibn Ṭūlūn, I'lām 109 (line 9-muntazirūna as a circumstantial adverb instead of muntazirina).

35 See, for example, Ibn Țūlūn, Mufākahat, ed. K. al-Manșūr 115, 134 (employs the nonclassical verb ghawwasha 'alā in the meaning of "reprimanded in shouting," see Dozy, Takmilat vii, 441); and see Ibn Țūlūn, Mufākahat, ed. K. al-Manșūr 159, 223, 375 (the nonclassical verb ittaqa'a, apparently in the meaning of "clashed"); and see ibid. 179-80, 267-8 (the nonclassical and colloquial az'ar in the meaning of "a brigand," and see Dozy, Takmilat v, 327; 'Abd al-Rahīm, Mawsū'at i, 136; for az'ar, see also Ibn Ṭūlūn, I'lām 118); and see Ibn Ṭūlūn, Mufākahat, ed. K. al-Manșūr 373 (the colloquial khashākhīsh, sing. khishkhāsh for "grave houses," see 'Abd al-Rahīim, Mawsūát i, 850). 
scholars who have made observations regarding the language of Ibn Tiūun seem to have focused on his vocabulary that draws on colloquial language. ${ }^{36}$ This also seems to have been the emphasis of Ibn Țūlūn's contemporaries, who criticized him for incorporating colloquial expressions (alfāz) in his writing. ${ }^{37}$ Be that as it may, Ibn Ṭūlūn seems to be more inclined to employ nonstandard usages in the frame of quoted dialogues or utterances in direct speech that appear in story-like reports or anecdotes in Mufäkahat al-khillān. ${ }^{38}$ Such reports with dialogues or utterances in direct speech are more common in Mufäkahat al-khillān ${ }^{39}$ than in the chronicles written by Ibn al-Furāt and Ibn al-Ṣayrafī (at least in accounts of contemporary events).

As for al-'Aynī (d. 855/1451), in his own reports on contemporary events in his chronicle Iqd al-jumān fi ta'rïkh ahl al-zamān, he refrained from using nonstandard Arabic. ${ }^{40}$ It may be added that in this part of his chronicle, story-like reports with dialogues are almost totally absent. ${ }^{41}$ There is evidence, however,

36 The remarks made by Muṣtafā were mentioned above. Similar remarks were made by Muhammad Aḥmad Dahmān in his introduction to I'lām al-warā regarding Ibn Ṭūlūn's language in general. Dahmān mentions that colloquial words or words that draw on colloquial language (kalimāt 'ämmiyya aw qarïba min al-ämmiyya) sometimes infiltrate into his texts, see Ibn Ṭūlūn, I'lām 16; and see also Fück, Arabiyya 571 ("influenced by the local dialect, especially in vocabulary"). On the "peculiar language" in Mufākahat al-khillān, see Tritton, Review 54-5.

37 İbish, Tảrīkh 78 (salaka fìmā awradahu 'alā țarīqat al-'awāmm wa-alfāzihim).

38 See, for example, Ibn Ṭūlūn, Mufākahat, ed. K. al-Manșūr 15-16 (15 line 2: absence of a conjunction, khudh-hā instead of fa-khudh-hā; 15 lines 4-5: esh and "broken" syntax that are typical of colloquial language; 15 line 21: absence of interrogative, which is typical of colloquial language. For absence of interrogative see also ibid. 33 o line 23); and see ibid. 24 (lines 4-5: esh and a derivative of the verb rāha in the meaning of "went [at any hour of the day]," which is typical of colloquial language, see Haarmann, Kanz 37); and see Ibn Ṭūlūn, Mufākahat, ed. K. al-Manșūr 87 (line 19: fì ayna in the meaning of "where?" which is not typical of standard Arabic and perhaps reflects the colloquial fèn; line 2o: absence of interrogative); ibid. 145 (line $5:$ innā kunnā dhahabnā -repetition of pronouns typical of colloquial language; line 6: the colloquial $a z^{\text {'ar }}$ in the meaning of "a brigand"; line 7: asyndetic subordinate object clause and/or imperfect plural masculine form in the indicative without the ending $n$-arādū yajrahūn̄i instead of arādū an yajrahūūì); ibid. 162 (line 22: imperfect masculine plural form in the indicative without the ending $n-y u q a \bar{t} i l u \bar{n} a \bar{a}$ instead of yuqātilūnanāa); ibid. 232 (lines 22-3: shortening of a long vowel in an unstressed syllable-jawāri al-nāìb, "the governor's slave girls," instead of jawārī $a l-n \bar{a} i b$, and see chapter 1 footnote 39).

39 For examples, see also Ibn Țūlūn, Mufākahat, ed. K. al-Manșūr 31, 5o, 106, 115, 218, 242-3, 288, 292, 376-7, 392, 394, 406, 411.

40 See appendix A group B no. 2 (footnote 189).

41 In the historical narrative of the years $824-7 / 1421-4$, I came across two short dialogues; see al-'Aynī, Iqd, ed. al-Qarmūṭ 152, 177 . 
that when describing past events, al-'Aynì may have allowed himself to preserve some nonstandard usages employed by his quoted sources. Little observed that al-Aynī transformed al-Yūsufì's colloquial usages into standard Arabic. ${ }^{42}$ However, at least in a few cases, he preserved some of al-Yūsufî's nonstandard usages, mainly in the frame of quoted dialogues in story-like reports. ${ }^{43}$ More importantly, al-'Aynī was accused by the Shāfi'i religious scholar Ibn Ḥajar al'Asqalānī (d. 852/1449) of quoting Ibn Duqmāq without correcting his linguistic mistakes, and this was perhaps not merely propaganda, because there is evidence that al-Aynī actually preserved in the narrative line of Iqd al-jumān some nonstandard usages of Ibn Duqmāq's Nuzhat al-anām. ${ }^{44}$ Only further research will be able to determine if Ibn Hajar's accusations are correct and to what degree al-'Aynī was willing to employ nonstandard usages of Arabic, and if such usages were the result of lack of attention. At this point, however, it seems reasonable to assume that at least in accounts of past events, al-'Aynī did not totally refrain from employing nonstandard usages of Arabic.

\section{Historians Who Were Religious Scholars: Shāfi'is}

As for historians who were Shāfīi religious scholars (group E in appendix A), the trend is quite different. ${ }^{45}$ Almost all Shāfici i historians seem to have been trying consciously and systematically to refrain from nonstandard usages of Arabic. As far as I know, no modern scholar has observed that the Shāfiì historians surveyed in appendix A employed nonstandard usages of Arabic, at least not in any significant manner (one exception will be mentioned below). Of course, every effort has its limits and sometimes, due to lack of attention, such nonstandard usages slipped into their writing. ${ }^{46}$ How important it was

42 Little, Recovery 44; Analysis 26o.

43 See appendix A group B no. 2 (footnote 188).

44 See appendix A group B no. 2 (footnote 189).

45 It should be emphasized that the discussion here does not concern historians who were officially affiliated with the Shāfi'i school of law but specialized as $u d a b \bar{a}^{\prime}-k u t t a \bar{b}$. I discuss this group (group D in appendix A) in section 6.1 below.

46 For some minor deviations from standard Arabic (mainly related to orthography) in alMaqrīzī's (d. 845/1442) draft notebooks, probably due to lack of attention and the speed of writing that are typical of drafts and notebooks, see Bauden, Maqriziana VIII 21-36; and see also, Maqriziana II 84-6; and see appendix B (no. 2 at footnote 225) for an example of a deviation (lack of standardization of a quoted source) in al-Dhahabī's (d. 748/1348) Ta'rīkh al-Islām; and see also appendix C (footnote 247) for an example of a deviation (lack of standardization of a quoted source) in Ibn Qāḍī Shuhba's (d. 851/1448) chronicle. 
for Shāfi'i historians to keep their language as clean as possible from nonstandard usages of Arabic, and how much effort they put into achieving this goal, becomes clear when comparing Shāfi'i historians' quotations of earlier sources with the original texts. It soon becomes clear that Shāfíi historians consistently standardized nonstandard usages of Arabic that were employed by the historians they quote, whether related to the military institution, to the Hanbalī or Hanafì schools of law, or to the kuttāb-udaba $\bar{a}^{3}$ tradition (see especially appendixes B and C). ${ }^{47}$ The importance that Shāfi is ascribed to standard Arabic becomes clear also when realizing that accusations regarding improper usages of Arabic were always headed by Shāfi îs against historians of military, Ḥanbalī, or Ḥanafĩ background, and never the other way around..$^{48}$ Of course, accusations may be mere propaganda. However, even if only propaganda, it shows that the Shäfi'is aimed at constructing their image as guardians of the Arabic language. As far as we can tell at this point, however, the historians accused by the Shāfi'is of employing nonstandard usages of Arabic, in fact, really did so (the case of al-Aynī should be further examined). Moreover, it seems that Shāfi'is were making great efforts to keep their own theoretical standard also in practice.

At times it is possible to see how Shāfici historians standardize nonstandard usages in sources used by them, whereas Ibn Taghrïbirdī, (a Hanafì) related to the military institution, preserves some of these usages (see table 2.1 below). The first example in table 2.1 is straightforward. It exemplifies how the Shāfi'i

The Shāfīi al-Dhahabī standardizes al-Jazarī related to Ḥanbalī circles (see appendix A group E no. 1; for a detailed comparison and discussion, see appendix B). The Shāfíi Ibn Kathīr (d. 774/1373) standardizes al-Birzālī related to Hanbalī circles (see appendix A group E no. 2; and see appendix A group C footnote 200). The Shāfīi al-Maqrīzī standardizes the military man al-Yūsufĩ and the Ḥanafì Ibn al-Furāt (see appendix A group E no. 3; and see chapter 1 table 1.2 and footnote 48). The Shāfi'īs Ibn Qāḍī Shuhba/al-'Ajlūnī standardize the military man al-Shujāīi (see appendix A group E no. 4 and footnote 212; for a detailed comparison, see appendix C). The Shāfíi Ibn Ḥajar al-'Asqalānī standardizes the adīb alȘafadī [d. 764/1363] (see appendix A group E no. 5; and see appendix A group D no. 2 footnote 203; and see table 2.1 below).

48 The Shāfíī al-Dhahabī accuses al-Jazarī related to Ḥanbalī circles (see appendix A group E no. 1; and see appendix A group C no. 2). The Shāfīi Ibn Ḥajar al-'Asqalānī criticizes alYūsufì and (the Ḩanafì) Ibn Duqmāq related to the military institution and the Hanafĩ al-'Aynī (appendix A group E no. 5; appendix A group A [soldiers] no. 4; appendix A group A [mamlūks' descendants] no. 2; appendix A group B no. 2). The Shāfici al-Sakhāwī (d. 9o2/1497) criticizes (the Ḥanafīs) Ibn Duqmāq and Ibn Taghrībirdī related to the military institution and the Ḥanafīs Ibn al-Furāt and Ibn al-Ṣayrafĩ (see appendix A group E no. 7; appendix A group A [mamlūks' descendants] nos. 2, 3; appendix A group B nos. 1, 3). The Shāfi'i Mūsā b. Yūsuf al-Ayyūbī al-Anșārī (d. 100o/1592) criticizes the Ḥanafì Ibn Ṭūlūn (see appendix A group B no. 4). 


\section{Ibn Ḥajar-al-Ṣafadī versus Ibn Taghrībirdī—al-Ṣafadīī}

al-Ṣafadī, $a l-W a \bar{f} \mathfrak{i}^{\prime}$

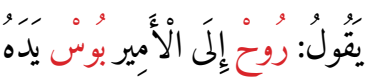

Ibn Taghrībirdī, al-Manhal al-șăfı
al-Ṣafadī, Áyān al-'aṣr

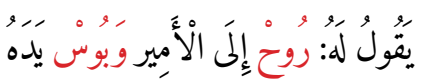

Ibn Ḥajar, al-Durar al-kāmina

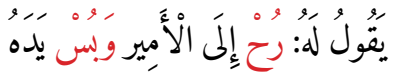

2. al-Maqrīzī—(Ibn al-Furāt?)—Ibn Duqmāq; versus Ibn Taghrībirdī—Ibn Duqmāq; and versus Abū Ḥāmid al-Maqdisī-Ibn Duqmāq

Ibn Duqmāq, al-Nafha al-miskiyya ${ }^{\mathrm{b}}$

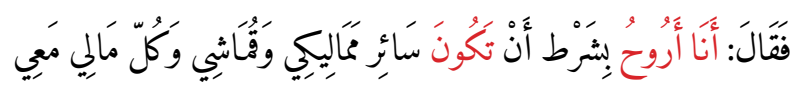

Ibn Taghrībirdī, al-Manhal al-șăfì /al-Nujūm al-zāhira ${ }^{\mathrm{c}}$

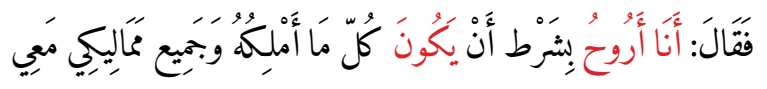

Abū Ḥāmid al-Maqdisī, Kitāb Duwal al-Istām ${ }^{\mathrm{d}}$

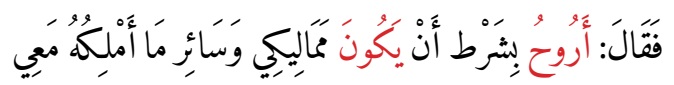

al-Maqrīzì, al-Sulūk/al-Khițaț

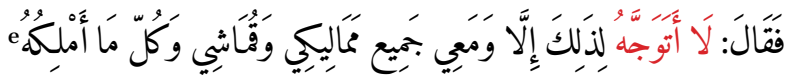

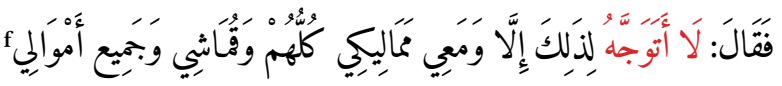

\footnotetext{
a For references, see appendix A group D no. 2 (footnote 203).

b Ibn Duqmāq, Nafha 212.

c Ibn Taghrībirdī, Nujūm xi, 6o; Manhal iii, 42.

d Al-Maqdisī, Duwal 75 .

e Al-Maqrīzī, Sulūk iii, 213.

f Al-Maqrīzī, Khițațiv, 257-8.
}

Ibn Ḥajar al-'Asqalānī standardizes al-Ṣafadī (d. 764/1363), whereas Ibn Taghrībirdī preserves al-Ṣafadī's nonstandard usages (for details, see appendix A, group D, no. 2, footnote 203).

The second example in table 2.1 is somewhat speculative; however, there is no doubt that the origin of the material is Duqmāqian. Considering what 
we know about the sources of Ibn Taghrībirdī and al-Maqrīzì (d. 845/1442) for events of the last quarter of the 8 th/14th century (the utterance in direct speech in the table is taken from a report on an event that took place in 775/1373), it is relatively safe to assume that Ibn Taghribirdi took the materials from Nuzhat al-anām ${ }^{49}$ and that al-Maqrīzī's text is of Duqmāqian origin (Nuzhat al-anām); however, he probably took it from Ibn al-Furāt. ${ }^{50}$ In Ibn Duqmāq's text we find the expression "anā arūḥu" (I will go), which employs the verb rāha and repeats the pronoun, which are typical of colloquial language. Apparently, there is also

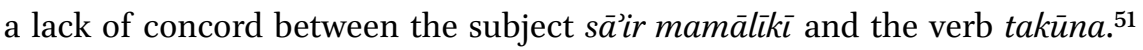
Ibn Taghrïbirdī preserves "ana arühu" but bypasses the lack of gender concord by paraphrasing the sentence. Al-Maqrīzì on the other hand gets rid of all the nonstandard usages in Ibn Duqmāq's text. ${ }^{52}$ The Shāfīi historian and religious scholar Abū Hāmid al-Maqdisī (d. 888/1483) undoubtedly took the text directly from Ibn Duqmāq's al-Naf̣̂a al-miskiyya ${ }^{53}$ Al-Maqdisī drops the repetition of the pronoun and bypasses the lack of gender concord; however, he preserves the verb răha. Al-Maqdisis's language is in fact an exception to the general trend

49 See Massoud, Chronicles 62.

50 See chapter 1 footnotes $47^{-53}$.

$5^{1}$ On lack of gender concord in Middle Arabic, see Blau, Handbook 46 (no. 82).

$5^{2}$ It has been generally noted (without giving examples) that in the Khitat al-Maqrīzi employed nonstandard usages of Arabic, see Rizq Salīm, al-Adab 21. However, here we see that in the Khițat al-Maqrīzī standardizes materials of apparently Duqmāqian origin. There is also evidence that al-Maqrīzì standardized in the Khițaṭ materials from al-Yūsufì: compare the report on qanāțir al-sibāc in al-Maqrīīi, Khițaț iii, 26o-1 with alYūsufī, Nuzhat 264-5. Trends of standardization in the Khițaț, however, should be further examined.

53 Compare Ibn Duqmāq, Naf̣̣a 212 (lines 1-7) with al-Maqdisī, Duwal 75 (lines 5-11). AlMaqdisī standardizes most of the nonstandard usages in al-Nafha al-miskiyya (see footnotes 1-2 in Ibn Duqmāq, Nafha 212, where the editor mentions what the standard form should have been, and compare with al-Maqdisiss text). However, he preserves some of the nonstandard usages. Haarmann thought that in the account of events of the Mamluk period in Kitāb Duwal al-Islām, al-Maqdisī relied heavily on al-Maqrīzī, who was his teacher (and on Ibn Taghrībirdī); see Haarmann's introduction in al-Maqdisī, Duwal 4553. Moreover, according to Haarmann, al-Maqdisī allowed himself to transform the language of al-Maqrīzī into colloquial language-"al-Maqrīzìs correct Arabic is elegantly transformed into colloquial Arabic"; see Haarmann, al-Maqrīzī 158. I cannot elaborate on it in the scope of this paper, however, most of the accounts of events of the Turkish period of the Mamluk Sultanate in Kitāb Duwal al-Isläm are in fact word-for-word quotations of al-Nafha al-miskiyya, which makes up the backbone of extensive parts of Kitāb Duwal alIslām. Al-Maqdisī standardizes many of the nonstandard usages in al-Nafha al-miskiyya but keeps many other nonstandard usages. He is by no means turning al-Maqrīzī's standard Arabic into colloquial language. 
of standardization exhibited by historians who were Shāfīi religious scholars. ${ }^{54}$ As Haarmann has argued, however, al-Maqdisī was far from being a typical religious scholar and historian. After being ridiculed by his colleagues who did not consider him intelligent enough, he wrote a treatise, praising the Mamluk rulers and criticizing his fellow ulam $\vec{a}$. His case is perhaps more a matter for the psychologist than the linguist. ${ }^{55}$

\subsection{Some Notes on Language Use in Drafts and Diaries/Journals, and on the Level of Religious Education of the Historians}

Before concluding that the trend of standardization was specifically typical of Shāfi'iss, three factors should be taken into consideration: the status of the manuscripts upon which the linguistic observations are based, the genre of the treatises, and the level of the authors. One would expect more usages of nonstandard Arabic in drafts or unedited diary-like records written on a daily basis without much revision. ${ }^{56}$ Among the historians who were Hanafĩ religious scholars, Ibn al-Furāt's chronicle is, in fact, a draft manuscript, ${ }^{57}$ and Ibn Țūlūn's Mufäkahat al-khillān consists mainly of diary entries. ${ }^{58}$ There is no evidence that Ibn Țūlūn edited or revised the diary-like material. ${ }^{59}$ However, it has been suggested that the diary material in Mufäkahat al-khillān starts, in fact, in $921 / 1515,{ }^{60}$ and nonstandard usages are found in this work also before that year. As for drafts of Shāfi'i religious scholars, in the autograph draft notebooks of al-Maqrīīi, Bauden found only some minor deviations from standard Arabic (mainly related to orthography), probably due to lack of attention and the speed of writing that are typical of drafts and notebooks. ${ }^{61}$ In the autograph draft of Izhāar al-aṣr, the chronicle of al-Biqā̄i (d. 885/148o), which has diaryor journal-like qualities, no conspicuous usages of nonstandard Arabic have been observed. ${ }^{62}$ This seems to be the case also with the autograph draft of

54 See appendix A group E (exception - footnote 219).

55 Haarmann, Rather $61-77$ (esp. 71-2). It may also be noted that his historical works are only partially subjugated to the annalistic traditional form.

56 On unedited diary records, see Wollina, Ibn Ṭawq 343-7 (esp. 345); and see also Conermann and Seidensticker, Remarks 121-7.

57 See appendix A group B no. 1.

$5^{8}$ Conermann, Ibn Ṭūlūn 131; Hirschler, Islam 283.

59 Conermann, Ibn Ṭūlūn 131.

6o Ibid. On Ibn Ṭūlūn's revision of materials prior to this date, see the editor's introduction in Ibn Ṭūlūn, Mufākahat, ed. M. Mușțafā ii, 16-8.

61 Bauden, Maqriziana viII 21-36; and see also, Maqriziana II 84-6.

62 See appendix A group E no. 6. On the diary-like qualities of Ižhāral-'așr, see Guo, al-Biqāè's 132; Tales 119; but see Wollina, Ibn Țawq 345 (at footnote 48). 
Inbā' al-ghumr, the chronicle of Ibn H.jajar al-'Asqalānī dedicated to his lifetime. ${ }^{63}$ In contrast, a substantial number of nonstandard usages of Arabic may be found in the autograph draft of the chronicle of Ibn Qâdị Shuhba (d. 851/1448). These, however, were in all likelihood parts of word-for-word quotations of selected sources used by Ibn Qādī Shuhba, which he intended to standardize in the fair copy, and they were eventually standardized by his student under his supervision. ${ }^{64}$ Similarly, we find in al-Dhahabỉs (d. 748/1348) autograph manuscript of a selection of reports from al-Jazari's chronicle (alMukhtār min Ta’īkh Ibn al-Jazarī) almost word-for-word quotations, which preserve some nonstandard usages of al-Jazarī. These reports were used by alDhahabī as raw material, some of which were later incorporated into his historical works, however, not before being standardized (see appendix B, especially at footnotes 226-8). In comparison to the abovementioned drafts of Shāfi i historians, in the draft of the chronicle of the Hanafī Ibn al-Furāt, the nonstandard usages are far more numerous and seem to reflect the language of Ibn al-Furāt himself and not necessarily the language of the sources he is quoting.

And what about the level of religious scholars? Perhaps the Shāfi'i religious scholars refrained from employing nonstandard usages of Arabic because they were highly educated, and not specifically because they were Shāfi īs? ${ }^{65}$ After all, al-Maqdisī, the only Shāfīi religious scholar employing nonstandard usages of Arabic in a conspicuous manner, cannot be considered a high-level religious scholar. Among the Ḥanafī religious scholars, Ibn al-Furāt and Ibn al-Ṣayrafì perhaps cannot be considered high-level religious scholars. Notwithstanding this, the fact that the relatively highly educated Hanbalì al-Yūnīnì and Ḥanafì Ibn Ṭūūn, and possibly also the highly educated Ḥanafì al-'Aynī, allowed themselves to employ nonstandard usages of Arabic suggests that specifically Shāfi'îs

63 On the draft, see the editor's introduction in Ibn Ḥajar al-'Asqalānī, Inb $\bar{a}^{\prime}$ i, 23. Nonstandard usages seem to be rare. Interestingly, in one of the manuscripts of this work in the possession of his student al-Biqāì margins, suggesting that the aim of Shāficis was to avoid such usages as much as possible; see ibid. iv, 22 (footnote 4).

64 See appendix A group E no. 4 (footnote 212); and see appendix C. Ibn Qāọī Shuhba is known to have gathered a selection (muntaq $\bar{a})$ of reports from the chronicles of Ibn alFurāt and Ibn Duqmāq, some of which were later incorporated in his historical works; see Massoud, Chronicles 35, 83 .

65 And see the remarks of Thomas Bauer and Thomas Herzog that "highly educated" or "highbrow" 'ulam $\bar{a}$ ' (they are not referring to historians specifically) avoided colloquial genres in order to not endanger their reputation and saw in the flawless mastering of Arabic grammar a means to differentiate themselves from lesser-educated aspirants; see Bauer, Misunderstandings 110; Herzog, Mamluk 145. 
refrained from nonstandard usages of Arabic as a mechanism of social distinction and as a way to emphasize their "Arabness," mainly in opposition to foreign Hanafĩ scholars. ${ }^{66}$

\subsection{The Importance of Arabness and the Arabic Language for the Shäfits}

In Mamluk biographical dictionaries dedicated to prominent contemporary persons, roughly $30-40 \%$ of religious scholars identified as Shāfi'is have an Arab tribal nisba or (less commonly) a nisba that traces their origin to a prominent Arab historical figure. ${ }^{67}$ The percentage is similar in most Mamluk biographical dictionaries dedicated exclusively to Shāfiì scholars. R.K. Jaques has noted that in Ibn Qāḍi Shuhba's biographical dictionary dedicated to Shāfi'i scholars (Tabaqāt al-Shāficiyya), tribal affiliation is mentioned in $31 \%$ of the biographical entries. ${ }^{68}$ However, according to my count, in biographical entries of Shāfi iss, who died in the 7 th/13th and 8th/14th centuries, an Arab nisba is mentioned in roughly $40 \%$ of the biographical entries. In Ibn Kathīr's (d. 774/ 1373) Țabaqāt al-Shäfíiyya, in biographical entries of Shāfi'is who died in the

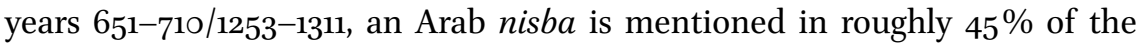
entries. In Tāj al-Dīn al-Subkī's (d. 771/1370) Ṭabaqāt al-Shāficiyya al-kubrā, in biographical entries of Shäfi'is who died in the 7 th/13th and 8th/14th centuries, an Arab nisba is mentioned in roughly $25 \%$ of the biographical entries. ${ }^{69}$

66 In this context, see also Levanoni, Who were 74-6; Supplementary $155^{-6 .}$

67 In al-Ṣafadī's $A$ 'yān al-'aṣr and in Ibn Ḥajar al-'Asqalānì's al-Durar al-kāmina almost $30 \%$ of the Shāfi'is have a nisba indicating an Arab origin. In the first seven volumes of Ibn Taghrībirdī's al-Manhal al-șăfì, almost $40 \%$ of the Shāfi'īs have a nisba indicating an Arab origin. It should be made clear that the actual percentage of Shāfiìs who had (or at least claimed to have) Arab origin was probably somewhat higher. I have restricted myself to counting nisbas in specific sources and did not combine information from all sources, nor did I thoroughly examine the origin of scholars mentioned in biographical dictionaries. Some prominent Shāfīi scholars are mentioned in some sources with an Arab nisba and in other sources without that nisba. It is quite possible that in their cases, it was sufficient to mention only their lineage and "family name," which were known to have been connected to an Arab origin. For example, members of the Subkī family are sometimes identified as Khazrajīs or Anșārīs but at other times simply as Subkīs. In his Ṭabaqāt alShāficiyya al-kubrā, Tāj al-Dīn al-Subkī himself identifies his family members simply as Subkīs; however, in the biographical entry of his grandfather, he mentions that he found in his writings that the tribes in the area of al-Subkiyya (ma'āshir al-Subkiyya) are Anșāīis; see al-Subkī, Tabaqāt x, 91 .

68 Jaques, Authority 263.

69 Al-Subkī, as mentioned, does not mention a tribal nisba in biographical entries of his family members. According to Jaques, Ibn Qāọī Shuhba's interest in tribal affiliation seems to be untypical for Shāfici Tabaqāt texts and is more typical of history works; see ibid. 263- 
In contrast, only roughly $10-15 \%$ of religious scholars identified as Ḥanafis in Mamluk biographical dictionaries dedicated to prominent contemporary persons have an Arab nisba. ${ }^{70}$ On the other hand, in these dictionaries about $30-$ $40 \%$ of the Hanafis have a non-Arab ethnic nis $b a$, or geographical nisba, suggesting an origin in Iran and its contiguous areas, Transoxiana, the Indian subcontinent, Central Asia, and Anatolia. ${ }^{71}$ Only roughly $15 \%$ of religious scholars identified as Hanbalīs in Mamluk biographical dictionaries dedicated to prominent contemporary persons have an Arab nis $b a,{ }^{72}$ although only approximately $7 \%$ of them have a non-Arab ethnic nisba or geographical nisba, suggesting an origin in the aforementioned areas. ${ }^{73}$ Thus, it would seem that

4. Among the Mamluk Shāfiı̀ Ṭabaqāt works, Jaques mentions the works of al-Subkī and al-Isnawī (d. 772/1370) but does not mention Ibn Kathīr's work. According to Jaques, alIsnawī mentions tribal affiliation in only $6 \%$ of biographical entries and al-Subkī in less than $10 \%$ of the biographical entries. According to my count, however, al-Subkī mentions Arab nisba in roughly $20 \%$ of the biographical entries and, as mentioned, in roughly $25 \%$ of biographical entries of Shāfi îs who died in the 7 th/13th and 8th/14th centuries. It thus seems that, at least with respect to Mamluk Shāfici Tabaqāt works, the exception is not Ibn Qāḍī Shuhba but rather al-Isnawī, who does not tend to mention tribal nisbas and focuses on geographical nisbas.

70 In al-Ṣafadī's $A$ 'yān al-'așr about $10 \%$ of the Ḥanafîs have a nisba indicating an Arab origin; in Ibn Ḥajar al-'Asqalānī's al-Durar al-kāmina about $15 \%$; in the first seven volumes of Ibn Taghrībirdì's al-Manhal al-șāf $ı$ about $12 \%$.

71 In al-Ṣafadī's Áyān al-'aṣr and in Ibn Ḥajar al-'Asqalānī's al-Durar al-kāmina about $30 \%$. In the first seven volumes of Ibn Taghrïbirdì's al-Manhal al-șăfi about 40\%. In comparison, in these dictionaries only $10-15 \%$ of Shāfi'is have a non-Arab ethnic nisba or geographical nisba suggesting an origin in the aforementioned areas. Moreover, among the Shāfiīs with foreign geographical nisbas, some scholars are also, at times, identified by an Arab tribal nisba, or are known to have been Arab, and/or are known to have been born in the territories of the Mamluk Sultanate. On foreign scholars who migrated to Cairo during the Mamluk period, many of them Hanafiss, see Petry, Civilian $61-77,154^{-}$ 7 .

72 In al-Ṣafadī's A'yān al-'așr and in the first seven volumes of Ibn Taghrībirdì's al-Manhal alșăfi about $15 \%$. In Ibn Ḥajar al-'Asqalānī's al-Durar al-kāmina about $12 \%$. The percentage is similar in Mamluk biographical dictionaries dedicated exclusively to Hanbalīs. In Ibn Rajab's (d. 795/1393) al-Dhayl 'alä Tabaqāt al-Hanābila tribal affiliation is mentioned in about $15 \%$ of the biographical entries of Hanbaliss who died in the 7 th/13th and 8th/14th centuries. It should be noted that biographical dictionaries dedicated exclusively to Hanbalīs give much more room for Iraqi scholars that are not mentioned in Mamluk biographical dictionaries dedicated to contemporary prominent persons, which normally focus on Mamluk scholars.

73 In al-Ṣafadī's A'yān al-'aṣr about 6\%. In Ibn Ḥajar al-'Asqalānī's al-Durar al-kāmina about $7 \%$. In the first seven volumes of Ibn Taghrībirdī's al-Manhal al-șāfi about $8 \%$. Such nisbas are mentioned in about $7 \%$ of the biographical entries of Hanbalis who died in the

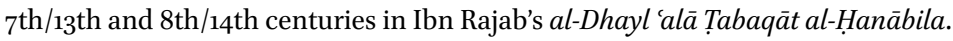


Shāfi'is emphasized their "Arabness" and considered it an important element of their collective identity. ${ }^{74}$

Shāfi'is took pride in their eponym's Arab descent, and more specifically his Qurashī, and even Hāshimī-Muțallibī, descent. As has been shown by Ella Landau-Tasseron, starting from the 3rd/9th century, Muhammad b. Idrīs alShāfi'ìs (d. 204/820) followers emphasized his meritorious descent as part of their efforts to construct his legitimacy and authority as a jurist, whereas his opponents tried to deny this descent in order to defame him. ${ }^{75}$ Importantly, Shāfi'i religious scholars of the Mamluk period, among them historians, were actively participating in this discourse. In Manāqib al-Shäfic literature or biographies dedicated to al-Shāfi'i during the Mamluk period, Shāfi'i religious scholars preserve the image of their eponym as a Qurashī and Muṭallibì and "a cousin of the Prophet" (ibn 'amm Rasül Allāh). ${ }^{76}$ His affiliation with the Prophet's clan and his noble descent (sharaf nasabihi) is considered as one of his merits $($ faḍ $\vec{a} i l) .{ }^{77} \mathrm{He}$ is said to have had the intelligence of the Qurashīs (Qurashī al- $\left.{ }^{-} a q l\right) .{ }^{78} \mathrm{He}$ is described as a leading religious scholar from Quraysh (imām 'ālim min Quraysh/imām Qurashī), and this descent is used to claim his superiority over other religious scholars. ${ }^{79}$ Thus, it is not surprising that Shāfi'îs took pride in Qurashī descent ${ }^{80}$ and even used it to construct their authority. As has been noted by Jaques, in his Tabaqāt al-Shāficiyya, Ibn Qāḍ̄ Shuhba was arguing that his meritorious Qurashī descent is an important part of his authority as a jurist. ${ }^{81}$

Al-Shāfi 'ì, who, according to some traditions, was born in Yemen, is said to have been sent to Mecca by his mother because she wanted him to be like his family and was afraid that living in Yemen would blur the quality of his descent (ilhaq bi-ahlika fa-takūna mithlahum fa-innī akhäfu an yughlaba 'alā

74 Among the Ḥanafiss, the non-Arab element was strong. The fact that Ḥanbalis normally do not have a non-Arab nisba but are still represented by Arab nisbas much less than Shāficis suggests that using an Arab nisba was not necessarily a matter of social background but a matter of ideology. However, one should consider also a regional factor: Most Mamluk Shāfiī religious scholars in biographical dictionaries are Egyptians whereas most Mamluk Huanbalīs are Syrian.

75 Landau-Tasseron, Cyclical 10o-2; and see also Ali, Imam 68.

$7_{6}$ Ibn Kathīr, Manāqib 6o-1; Tabaqāt i, 18-9 (his mother is said to have been of the Azd tribe, which is the "source" of all Arabs [jurthūmat al-Arab]); and see also Ibn Qudāma al-Maqdisī, Manāqib 104 (shaqīq Rasūl Allāh fì nasabihi wa-sharīkuhu fi ḥasabihi).

77 Ibn Kathīr, Manāqib 126; Ibn Ḥajar, Manāqib 29, 102.

78 Ibn Kathīr, Manāqib 148; Ibn Ḥajar, Manāqib 83, 95.

79 Ibn Kathīr, Manāqib 138; Ibn Hajar, Manāqib 39; Ibn Qāḍī Shuhba, Manāqib 64-5.

8o See for example Ibn Faḍl Allāh al-'Umarī, Masālik 156.

81 Jaques, Authority 258-66. 
nasabika). ${ }^{82}$ Al-Shāfi'i is said to have stayed with Arab (Bedouin) tribes from childhood and to have learned their poetry and language for 20 years. According to several traditions, al-Shāfi'i stayed with the tribe of Hudhayl, considered to be the most eloquent among the Arab tribes (afșah al-Arab). ${ }^{83}$ His descent from the Prophet's clan (bayt al-nubuwwa) and his upbringing among the Arab tribes explains why he was the most knowledgeable in the Arab science of physiognomy ( firāsa), poetry (shir r), the battles of the Arabs (ayyām al-Arab), and the genealogy of the Arabs (ansāb).${ }^{84}$ During the Mamluk period, the focus that Shāfi'iss put on Arab genealogy is also illustrated by the dominant role they played (at least in Egypt) in the production of treatises on the genealogy of Arab tribes. Probably the most conspicuous examples are Nihāyat al-arab $f i$ ma'rifat qabä̀il al-Arab and Qaläìd al-jumān fì l-ta'rḯf bi-qabäil 'Arabal-zamān, written by Abū l-'Abbās al-Qalqashandī (d. 821/1418), ${ }^{85}$ and al-Bayān wa-l-i'rāb

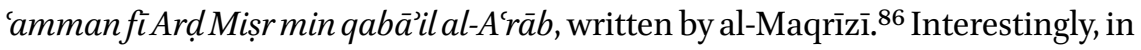
the introduction, al-Maqrīzi dedicates the treatise to his Arab kinsmen $\left(a b n \bar{a}^{2}\right.$ jinsī $) .87$

$82 \quad$ Ibn Kathīr, Ṭabaqāt i, 19.

83 Ibid., Manāqib 72-3; Țabaqāt i, 21; and see also Ibn Qudāma al-Maqdisī, Manāqib 122.

84 Ibn Hajar, Manāqib 97 (he knew the genealogy of men and women), 104, 105 (experts of poetry came to consult him); Ibn Kathīr, Țabaqāt i, 52-3; Manāqib 203-4, 208, and see also 169; Ibn Qāḍ̄ Shuhba, Manāqib 52-3, 6o, 70, 73, 81-2; Ibn Qudāma al-Maqdisī, Manāqib 119-20. On poetry written by al-Shāfi'ī, see for example Ibn Qāḍī Shuhba, Manāqib 49-51.

85 See Bauden, Like 200-3; Brockelmann, History 142-3.

86 See al-Maqrīzì, Rasā'il 123-54. Note that al-Maqrīzī authored a general history of humanity that dedicated an important place to the genealogy of the Prophet and the Arabs (Kitāb al-Khabar 'an al-bashar fi ansāb al-Arab wa-nasab sayyid al-bashar). In this treatise, al-Maqrīzī puts emphasis on the importance of the Arabs (and their language), extolls their superiority, and in fact, suggests that the Arabs (and Quraysh in particular) are the only ones entitled to power in Islam; see Ghersetti, Language $145^{-6}$. To these may be added Nihāyat al-arab fi ma'rifat ansāb al-'Arab, the work of the Shāfi'î Najm al-Dīn Muḥammad al-Qalqashandī (d. 876/1471), the son of Abū l-'Abbās al-Qalqashandī, which is an imitation (in fact, an appropriation) of his father's work; see Bauden, Like 20o3, 214; Brockelmann, History 143; and Qabäil al-Khazraj and Qabäil al-Aws attributed to the Shāfi'ì 'Abd al-Mu’min b. Khalaf al-Dumyāțī (d. 705/1306); see al-Ṣafadī, A'yān iii, 18o; Ibn Taghrībirdī, Manhal vii, 372; al-Zarkalī, A'ām iv, 169-70; al-Bābānī, Hadiyyat i, 631. According to al-Bābānī, the Shāfīi Egyptian scholar Badr al-Dīn Ḥasan b. Muhammad b. Ayyūb (d. 866/1461), known as al-sharîf al-nassāba, composed a treatise on the geneaology of Arab tribes entitled al-Jawhar al-maknūn fì l-qabä'il wa-l-buțūn; see ibid. i, 286. This, however, seems to be a mistake stemming from the fact that a treatise by that name was written by Muḥammad b. As'ad al-Jawwānī (d. 588/1192), also known as al-sharīf alnassāba; see al-Maqrīīi, Khițaț iv, 351-2. 
Most important to the discussion at hand, the Shāfi î tradition puts emphasis on al-Shāfi'i’s superior competence in the Arabic language. Before surveying the Shāfici tradition, it should be mentioned that in his Risāla, al-Shāficī himself was arguing that "God had sent down His Quran in Arabic, the mother-tongue of His Prophet" and "granted Muhammad-alone among humans-a comprehensive and perfect command of the language." 88 Arabic is perceived as a "sacral" and superior linguistic medium. ${ }^{89}$ Part of the genius of the Arabic language is that it is frequently ambiguous. ${ }^{90}$ This ambiguity "ensures a role for interpreters steeped in Arabic" and accounts for al-Shāfi'i's insistence on "the centrality of linguistic expertise for interpretation," his concern for nuances of the Arabic language, and his deep interest in words and language. ${ }^{11}$ Possibly, al-Shāfi'i even claimed that Arabs are superior to non-Arabs when he offered a theory of "divinely sanctioned ethno-linguistic superiority" and asserted that " $[t]$ he people most entitled to superiority in regard to language are those whose language is the language of the Prophet," ${ }^{92}$ implying that "all Muslims have an unconditional obligation to learn Arabic at the level of a native speaker" and that "non-Arabic speakers were not directly addressed by the Quran." Such assertions were rejected by Ḥanafì (non-Arab) jurists. ${ }^{93}$

Manāqib al-Shāfici and Shāfiì biographical literature written during the Mamluk period give a prominent place to al-Shāfi'ì's competence in the Arabic language (al-mahärafílughat al-'Arab), which is linked to his noble descent and him being a relative of the Prophet (sharaf al-nasab/nasīb Rasūl Alläh/qarābatihi min Rasūl Allāh). ${ }^{94}$ Al-Shāfíi is said to have been of Arab character and to have spoken an Arabic mother tongue ('Arabīal-nafs Arabī al-lisān). ${ }^{95}$ Al-Shāfici is said to have been acknowledged as the most eloquent person ( fașīh/afșah /afșah lisān) by his contemporaries. ${ }^{96} \mathrm{He}$ is also said to have been the most knowledgeable in the Arabic language (lisān al-Arab). ${ }^{97}$ The level of his Arabic was so high that when he wrote his books, he had to lower it

\footnotetext{
88 Burton, $A b \bar{u}$ 'Ubaid 21.

89 Lowry, Preliminary 509 (footnote 7); and see also Ali, Imam 67.

90 Burton, $A b \bar{u}$ 'Ubaid 22.

91 Ali, Imam 67-8; and see Ibn Qāḍī Shuhba, Manāqib 52-3.

92 Ali, Imam $67-8$.

93 Lowry, Preliminary 517.

94 Ibn Ḥajar al-Asqalānī, Manāqib 29, 101; Ibn Kathīr, Manāqib 165; Ibn Qāạī Shuhba, Manăqib 20; and see Ali, Imam 68.

95 Ibn Kathīr, Manāqib 207; Țabaqāt i, 53; Ibn Ḥajar al-'Asqalānī, Manāqib 96.

96 Ibn Kathīr, Manāqib 143, 146, 205, 207; Ṭabaqāt i, 22, 37, 52-3; Ibn Ḥajar al-'Asqalānī, Manāqib 78-9, 86, 9o, 97, 101; Ibn Qāḍī Shuhba, Manāqib 32, 72-3.

Ibn Qāḍī Shuhba, Manāqib 7o, and see also 66.
} 
down so that the people would understand him. ${ }^{98}$ His contemporaries, among them experts of the Arabic language, agreed that he was a master (faylasüf) of language (lugha) and an authority in linguistic matters (kaläm al-Shäfi fi l-lugha hujja/mimman tu'khadhu 'anhu al-lugha/imām fì l-lugha/hujja fì l$n a h w$ ). ${ }^{99}$ Experts in the Arabic language (ahlal-Arabiyya) came to consult him in matters related to the Arabic language. ${ }^{100}$ Experts of the Arabic language who spent a long time with him are said to have reported that he never spoke ungrammatical Arabic (lahnna). ${ }^{101}$ It is said that when someone read to al-Shāfi'i and made a mistake in Arabic (laḥana), al-Shāfi'i became troubled. ${ }^{102}$ Al-Shāfi'i is reported to have said that the people became ignorant only because they moved away from the language of the Arabs (kaläm al-Arab/lisān al-Arab).103 And one last anecdote: It is reported that al-Shāfici related that when he was still a young boy, he saw the Prophet in a dream. The Prophet asked him who he was, and al-Shäfi'i replied that he was a member of the Prophet's family ( $\mathrm{min}$ rahțika). The Prophet asked al-Shāfii to approach him and then took his saliva and rubbed it over al-Shāfi's's tongue, mouth, and lips and told him that he may leave and that now he was blessed. Since that day, al-Shāfici never made another mistake in Arabic ( $f a-m \bar{a}$ adhkuru annī lahantu). ${ }^{104}$ It has been noted by Jaques that the Shāfici Manāqib literature constructed a hagiographic vision of al-Shāfi'i that mimics the story of Muhammad's life. ${ }^{105}$ This anecdote is perhaps a reminder of the opening and purification of Muhammad's heart and his initiation into Prophethood. The changing of bodily fluids suggests, in fact, that the two became one. After his speech organs were rubbed by the Prophet's saliva, al-Shāfi'i acquired the Prophet's perfect command of the Arabic language. ${ }^{106}$ Given this Shāfi ì mythos and ethos, and given the fact that Shāfíi

\footnotetext{
98 Ibid. 51; Ibn Qudāma al-Maqdisī, Manāqib 119.

99 Ibn Kathīr, Manāqib 154, 207; Ṭabaqāt i, 40; Ibn Ḥajar, Manāqib 85, 96, and see also 102-3; Ibn Qudāma al-Maqdisī, Manāqib 119, 131; Ibn Qāḍ̄ī Shuhba, Manāqib 32, 511, 6o, 81.

$100 \quad$ Ibn Hajar, Manāqib 105; Ibn Qāọī Shuhba, Manāqib 6o.

101 Ibn Kathīr, Manāqib 206; Ṭabaqāt i, 53; Ibn Ḥajar, Manāqib 96; Ibn Qudāma al-Maqdisī, Manāqib 116; Ibn Qāạī Shuhba, Manāqib 32, 73.

102 Ibn Kathīr, Manāqib 208; Ibn Ḥajar, Manāqib 115.

103 Ibn Qāḍī Shuhba, Manāqib 51-2.

104 Ibid. 6o.

105 For example, al-Shāfi'i is described as member of the tribe of Quraysh and the Prophet's clan, and his father is said to have died when he was young, see Jaques, Other 159; and see also Ali, Imam 110-1.

106 In another anecdote (if I understand it correctly), it is said that whoever meets al-Shāfi ì will think that the Quran was sent down in his (i.e., al-Shāfi'ì's) language, see Ibn Qāḍī Shuhba, Manāqib 71-2.
} 
historians were actively participating in its preservation, it is hardly surprising that Shāfii historians would refrain as much as possible from nonstandard usages of Arabic. ${ }^{107}$

Manāqib, or biographical literature, of other schools of law do not put emphasis on their eponyms' competence in Arabic (at least not in the manner or intensity of the Shāfici tradition). The Shāfici tradition polemicizes with other schools when it has their eponyms acknowledge al-Shāfi'i's authority and eloquence in the Arabic language. ${ }^{108} \mathrm{~A}$ special place, however, is reserved for the non-Arab Abū Hanīfa (d. 150/767) and his followers. The Shāfíi tradition claims that al-Shāfi'i was an expert in Arabic because he was an Arab (tawahhada al-Shāfīi bi-l-lugha li-annahu min ahlihā), whereas Abū Hanīfa could not be blamed for any mistakes he made in Arabic because he was not an Arab (kāna khärijan min al-lugha). ${ }^{109}$ It is reported that when someone claimed that the followers of Abū Ḥanīfa were eloquent, al-Shāfiī started reciting poetry verses, boasting of his eloquence and degrading his opponents. ${ }^{110}$ In Hanafì Manāqib (or biographical) literature written during the Mamluk period, one senses a defensive or apologetic tone. Al-Kardarī (d. 827/1424), for example, rejects the Shāfi'ì claim that because al-Shāfi'i was a Qurashī from the Prophet's family and because he was more knowledgeable in the Arabic language he had greater authority as a scholar. Al-Kardarī mentioned that even the Qurashīs benefited from the knowledge of non-Arabs (mawālī $).{ }^{111}$ Some tried to claim that Abū Ḥanifa was of Arab origin; however, even Ḥanafis did not accept this view.112 Normally, the Ḥanafī tradition maintained that Abū Hanīfa was a descendant of a freed slave; however, some claimed that he was of non-Arab free origin, and others have ascribed to him a noble Persian descent. ${ }^{113}$ Most importantly, the Ḥanafì tradition claims that the accusations that Abū Hanīfa did not master the grammar of the Arabic language were not correct. ${ }^{114}$ Still, in chapters enumer-

107 It may be mentioned here that Mamluk Shāfici religious scholars, among them historians, were dominant in the field of tașhiff (misreading). All treatises on this subject written during the Mamluk period that were surveyed by Konrad Hirschler were written by Shāfīis, see Hirschler, Written 92.

108 On Aḥmad b. Ḥanbal (d. 241/855), see for example Ibn Kathīr, Manāqib 154, 207; Ibn Ḥajar, Manāqib 85-6; Ibn Qāḍī Shuhba, Manāqib 66; on Mālik b. Anas (d. 179/795), see for example Ibn Kathīr, Manāqib 207-8. Abū Hianifa (d. 150/767), who died in the same year al-Shāfíi was born, could not have met him.

109 Ibn Qāḍī Shuhba, Manāqib 81.

110 Ibid. 49-50.

111 Al-Kardarī, Manāqib 56.

112 Al-Dimashqī, 'Uqū 56-7.

113 See Ibid. 53-7; Ibn Abī l-Wafā̄ al-Qurashī, al-Jawāhir i, 49-53.

114 Al-Dimashqī, 'Uqūd 167. 
ating his merits in general (jumal min makārim akhlāqihi), knowledge of the Arabic language is not mentioned. On the other hand, knowledge of Persian is mentioned. ${ }^{115}$ Therefore, it is not surprising that non-Shāfi'i religious scholars who were historians, and more specifically Hanafis, felt less restricted by the norms of standard Arabic.

\section{$5 \quad$ Language and Style in Mamluk Chronicles}

At this point, it is possible to make two more general remarks regarding language and style in Mamluk chronicles. Ḥasan Ḥabashī (followed by Carl Petry) has posited a so-called "Cairo narrative style," which may be characterized as "a blending of colloquial and formal language unique to the second half of the 9th/15th century" and represented by Ibn Iyās. ${ }^{116}$ According to Habashī and Petry, the first representative of this style was Ibn al-Sayrafi. ${ }^{117}$ As noted by Haarmann, however, the term "Cairo narrative style," as specifically characteristic of the second half of the 9 th $/ 15^{\text {th }}$ century, is not appropriate, because "many sources of earlier times employ this amalgamation of the vernacular and fușhāa."118 Guo mentioned Ibn al-Dawādārī as "just another example of this phenomenon"119 and noted that it is typical of Egyptian historians related to the military institution in general. ${ }^{120}$ Guo concluded that "the enterprise of Ibn Iyās ... may better be placed within this long list of non-Arab Mamluk intelligentsia" whose linguistic and ethnic background must have had some influence on their language and style. ${ }^{121}$ As our survey has shown, not only is "the blending of colloquial and formal language" not specifically characteristic of the second part of the 9 th $/ 15^{\text {th }}$ century, it is also not specifically characteristic of Egyptian historians, or even historians related to the military institution. We have seen that usages of nonstandard Arabic are typical of Egyptian historians related to the military institution (Baybars al-Manșūrī being the exception), and of nonShāfici religious scholars in general (al-Birzālī and al-'Aynī possibly being the

\footnotetext{
115 Ibid. 275.

116 Guo, Mamluk 41; and see also, Introduction 96 (footnote 6o).

117 Ibn al-Ṣayrafī, Inb $\bar{a}^{3} 17-21$ (esp. 2o); Petry, Protectors 6.

118 Haarmann, Review of Twilight 637 (footnote 2).

119 Guo, Mamluk 41.

120 Ibid. 43.

121 Ibid. And see Guo's remarks concerning the debate about the existence of a so-called "Egyptian School," and his emphasis on differences in background and life experience and on the complex background of Egyptian historians in contrast to the more homogenous background of their Syrian counterparts, ibid. 29-30, 37-41.
} 
exceptions), ${ }^{122}$ but untypical of Shāfi'i religious scholars in general (al-Maqdisī being the exception). ${ }^{123}$ Therefore, language by itself cannot be a differentiating criterion of an "Egyptian style,"124 not even of a "military-related Egyptian style." 125

Adding to usages of nonstandard Arabic the criterion of the incorporation of story-like reports with dialogues and direct speech in accounts of contemporary events in the historical narrative (hawādith) in chronicles perhaps may allow us a more nuanced differentiation between groups of historians. As already noted, the combination of nonstandard usages of Arabic and story-like reports with dialogues is typical of Egyptian historians related to the military institution. ${ }^{26}$ In general, it is untypical of Shāfi'i religious scholars, and not only because they refrained from employing nonstandard Arabic. Al-Maqrīzì's Sulük has proven to be "dry" of story-like reports with dialogues containing direct speech in accounts of his own time. ${ }^{127}$ It would seem that Inbä al-ghumr and Wajiz al-kalām, the chronicles of the Egyptian Shāfiì historians Ibn Ḥajar al-'Asqalānī and al-Sakhāwī (d. 902/1497), are also "dry" of story-like reports with dialogues containing direct speech in accounts of contemporary events. ${ }^{128}$ Apparently, this holds true also regarding chronicles of Syrian Shāfi'i historians. The last parts of al-Dhahabīs chronicle Duwal al-Islam contain no story-like reports with dialogues or utterances in direct speech. However, it should be remembered that it is only a summary of important events in the history of

122 Ibn al-Furāt and Ibn al-Ṣayrafī are Egyptian. Al-Yūnīn̄ī, al-Jazarī, and Ibn Ṭūlūn are Syrian.

123 Al-Maqrīzī, Ibn Ḥajar al-'Asqalānī, al-Biqā̄ì̄, and al-Sakhāwī are Egyptian. Al-Dhahabī, Ibn Kathīr, and Ibn Qāḍī Shuhba are Syrian.

124 Therefore, it is not advised to consider Ibn al-Furāt as an "earlier exponent" of the "socalled 'Cairo narrative style'" only based on his usages of the Arabic language, see Bora, Mamluk 121-2 (footnote 7).

125 And see Nelly Hanna's remarks regarding usages of nonstandard Arabic in chronicles written in Ottoman Egypt by "civilians," see Hanna, Chronicles 248-9. See also footnote 153 below.

126 See section 2 above; and see chapter 1 section 1 footnotes 1-5; and see chapter 1 table 1.1.

127 For a detailed discussion, see chapter 1 section 2 at footnotes $59-61$.

128 This element seems to be almost totally absent from Wajiz al-kaläm. I have checked the years 881-4/1476-80 and did not find even one story-like report with dialogues, see alSakhāwī, Wajiz 871-903. In Inb $\bar{a}^{\prime}$ al-ghumr it seems to be relatively rare. I have checked the years 839-41/1435-8 in Inbä al-ghumr and located two cases of what may be considered as a dialogue, which are actually cases of a combination of utterances in direct speech (one of them, in fact, is a combination of two consecutive utterances of the same person in the course of a legal discussion with not much "story" around); see Ibn Ḥajar, Inb $\bar{a}$ ' iv, $44,49-5$. In a few other cases there are short utterances in direct speech (sometimes they consist of only two words). Normally, there is not much "story" around them, see ibid. iv, $13,48,7$. 
Muslim dynasties. ${ }^{129}$ Al-Dhahabỉs Ta'ïkh al-Islām is less relevant for the discussion because it ends in the year 700/1300-1 and normally contains material taken from earlier sources. Still, it may be mentioned that in the historical narrative of the last ten years in Ta'rikh al-Islām (691-700/1291-1301), one finds only two short dialogues and a few short utterances in direct speech. ${ }^{130}$ Importantly, however, it can be demonstrated that al-Dhahabì transferred long story-like reports with dialogues or many utterances in direct speech taken from the historical narrative (hawādith) of al-Jazarī's chronicle to the section of obituaries in Ta'îkkh al-Islām. ${ }^{131}$ This suggests that al-Dhahabì found the section of obituaries a more appropriate place for the incorporation of story-like reports with dialogues or many utterances in direct speech. As for Ibn Kathīr, in the account of events of the years 750-67/1349-66 in his al-Bidāya wa-l-nihāya, I came across seven relatively long story-like reports with dialogues, ${ }^{132}$ and five other utterances in direct speech. ${ }^{133}$ The number in itself is not that high, but not insignificant. However, most of the dialogues and utterances in direct speech do not appear in reports that are an integral part of the description of events but rather in disconnected stories that appear as digressions to the narrative line and are normally labeled as "strange" or extraordinary stories (amr gharīb/ujūba/nädira min al-gharāìib). ${ }^{134}$ For example, three out of the seven dialogues appear in "strange" stories: one is taking place in a "strange" dream (manām gharīb) that Ibn Kathīr dreamed, ${ }^{135}$ one is about a woman who suddenly grew a penis, which was questioned by Ibn Kathīr, ${ }^{136}$ and another is about a Shici who cursed the oppressors of 'Alī and was questioned by Ibn Kathīr. ${ }^{137}$ Another dialogue appears in a story about the khalīf al-Ma'mūn (r. $198-218 / 813-33$ ), integrated by Ibn Kathīr into the narrative, clearly as a digres-

129 The last 15 years of the chronicle (730-44/1329-44) have been checked and not even a single story-like report containing utterances in direct speech was found; see al-Dhahabī, Duwal ii, 273-92.

130 Al-Dhahabī, Tảrīkh lii, 12, 28, 51, 61, 72, 75, 79-8o, 101.

131 See, for example, a story-like report on the murder of sultan al-Ashraf Khalil that appears in the historical narrative in al-Jazarī's chronicle (al-Jazarī, Ta'rīkh i, 191-3) that was transferred by al-Dhahabī to the obituary of al-Ashraf Khalīl (al-Dhahabī, Ta'rīkh lii, 181-3). See also the story-like report on the fall of Ibn al-Sal'ūs in the historical narrative in al-Jazarî's chronicle (al-Jazarī, Ta’rīkh i, 193-4) that was transferred by al-Dhahabī to his obituary (alDhahabī, Ta’irīkh lii, 200).

132 Ibn Kathīr, Bidāya xiv, 285, 287, 297, 319, 332, 355, 359.

133 Ibid. xiv, 269, 275, 324, 336, 354.

134 Ibid. xiv, 285, 287, 332, 336; and see also xiv, 269 .

135 Ibid. xiv, 332.

136 Ibid. xiv, 285 .

137 Ibid. xiv, 287 . 
sion. ${ }^{138}$ Therefore, while the penchant of Ibn Kathīr for "strange" stories cannot be denied, ${ }^{139}$ formalistically, the incorporation of story-like reports with dialogues as an integral part of the accounts of contemporary events in his chronicle (and not as marginal "strange" stories) is relatively rare. The Egyptian al-Biqầi , on the other hand, is a true exception to the trend exhibited by Shâfi'is in general regarding the incorporation of story-like reports with dialogues in the historical narrative of contemporary events. In general, reading through al-Biqâi'i's chronicle one feels that he is being told story after story. It is relatively easy to find in his chronicle story-like reports with dialogues, some of them long, or utterances in direct speech, incorporated as an integral part in the account of contemporary events. ${ }^{140}$ Indeed, Guo has noted that his chronicle is a "deviation, in many ways, from mainstream historiography"141 and labeled it as a remarkable and "somewhat odd" work that has an "extraordinarily intimate nature."142 The narrative combines traditional narration, Quranic exegesis, and dream interpretation. ${ }^{143} \mathrm{Al}$-Biqâ̄ì's reports are not terse and matter-of-fact, and he puts emphasis on people's stories. ${ }^{144}$ His chronicle is full of anecdotes and dramatized "juicy stories" with gossip and sex scandals and bears a general mark of sensationalism. ${ }^{145}$ Perhaps it is noteworthy that he had some kind of military career; thus, his background was also somewhat odd. ${ }^{146}$

As for historians who were non-Shāfīi religious scholars, while it seems that, in general, they incorporated less story-like reports with dialogues in accounts of contemporary events in comparison to historians related to the military institution, they generally incorporated such elements more than their Shāfi'i peers (however, never forget al-Biqā̄ì!). The incorporation of these elements is common enough in the chronicles of the Hanbalīs al-Yūnīnī and al-Jazarīîn

\footnotetext{
138 Ibid. xiv, 319 .

139 Indeed, his chronicle has been labeled "popular" history by Guo; see Guo, History 451.

140 I have checked in detail the year 863/1458-9. For story-like reports with dialogues, see alBiqā̄i Tàrīkh iii, 17, 67, 72, 93. For utterances in direct speech, see ibid. iii, 6, 12, 14, 21, 53, $59,68,79,92$. For story-like reports with no dialogues or utterances in direct speech, see for example ibid. 70, 78. For story-like reports labeled as "strange" or extraordinary stories that contain utterances in direct speech, see, for example, ibid. iii, 86. For a report on a dream containing a dialogue, see ibid. 61 .

141 Guo, al-Biqāî̀'s 121.

142 Ibid., Tales 102.

143 Ibid.

144 Guo, al-Biqā̄î̀s 127.

145 Ibid. 131, 140. On "bizarre stories," miracles or wondrous stories, or dream-related stories, see Guo, Tales 110-2.

146 Ibid., al-Biqāî’’s 122.

147 See chapter 1 footnotes 8-9; and see also chapter 1 at footnote 1.
} 
and the Hanafì Ibn Țūlūn. ${ }^{148}$ While it is less common in the chronicle of Ibn alȘayrafi, ${ }^{149}$ and even less in the chronicle of Ibn al-Furāt, ${ }^{150}$ the two apparently incorporated more such elements than most of their Shāfii peers. For example, the chronicle of Ibn al-Furāt contains more such elements than the Sulūk, the chronicle of the Shāfíi al-Maqrīzī. ${ }^{151}$ The two exceptions to this general trend exhibited by non-Shāfi'ì religious scholars are the Hanbalī al-Birzâlī and the Ḥanafì al-'Aynī, in whose chronicles story-like reports with dialogues or utterances in direct speech are almost totally absent in the account of contemporary events. 152

To conclude the first remark, at least with respect to the two formalistic aspects that we have singled out here (i.e., usages of standard versus nonstandard Arabic and incorporation of story-like reports with dialogues and direct speech in accounts of contemporary events in the historical narrative in chronicles), the primary differentiation is not necessarily between Egyptian and Syrian writers but rather between historians related to the military institution (all Egyptian), Shāfīì religious scholars, and non-Shāfíī religious scholars. ${ }^{153}$ Non-Shāfīi religious scholars seem to take a middle ground between historians related to the military institution and historians who were Shāfici religious scholars. Still, just to remind us that things are not that simple, a secondary differentiation based on an Egyptian-Syrian dichotomy is perhaps useful. In general, Syrian Shāfīi religious scholars (most notably Ibn Kathīr) perhaps incorporated more story-like reports with dialogues than their Egyptian Shāfi'i counterparts, and Syrian non-Shāfī̄ religious scholars (al-Yūnīnī, al-Jazarī, and Ibn Ṭūlūn) definitely incorporated more story-like reports with dialogues than their Egyptian counterparts (Ibn al-Furāt, al-'Aynī, and Ibn al-Ṣayrafī). In addition, one may note that at least during the Circassian period, in general, it seems that Syrian non-Shāfi'ì religious scholars (Ibn Țūlūn) were more inclined than their Egyptian counterparts (Ibn al-Furāt and Ibn al-Ṣayrafi) to incorporate

\footnotetext{
148 See above at footnotes $38-9$.

149 See above at footnote 3 .

150 See above at footnote 29 .

151 See chapter 1 footnotes $54-9$; and see at footnote 127 above.

$15^{2}$ See chapter 1 footnote 12 ; and see above at footnotes 27,41 .

153 It has been noted that in chronicles written during the 17th and 18th centuries in Ottoman Egypt, employment of nonstandard Arabic, direct speech, and story-telling style was not restricted to authors of a military background (so-called "military chronicles") but was prevalent also in the works of artisans and traders ("civilian chronicles"); see Hanna, Chronicles 248-9. At least during the Mamluk period, such elements were employed also by (non-Shāfi'î) religious scholars, however, in general, apparently less than in chronicles written by authors related to the military institution.
} 
vocabulary (words or expressions) drawing on colloquial usages. On the other hand, in general, Egyptian non-Shāfici religious scholars (Ibn al-Furāt and Ibn al-Sayrafī) employed in the more formal narrative line some typical nonstandard usages of Arabic (mainly related to morphology or morphosyntax) more extensively than their Syrian counterparts (Ibn Ṭūlūn). ${ }^{154}$ A Reevaluation

The second remark has to do with Nasser Rabbat's theory regarding the representation of mamlüks by Mamluk historians. Our survey casts doubts on Rabbat's observation that numerous conversations between mamlüks are reported in colloquial Arabic as part of a deliberate negative (mis)representation of the mamlüks as uncouth and uncultured, and not only as a way to give the accounts an appearance of authenticity and immediacy, and make the accounts more entertaining and "popular" in order to attract a wider audience. ${ }^{155}$ After all, the historians related to the military institution and Hanafî religious scholars who were closest to the Mamluk regime employ nonstandard Arabic in dialogues (and not necessarily in ones involving mamlūks), ${ }^{156}$ whereas the Shāfiì religious scholars, who were the fiercest critics of the Mamluk regime, use standard Arabic when representing the mamlüks' speech in dialogues. This is not to say that representing a mamlük as speaking colloquial Arabic could not have been used to construct a negative image in specific cases ${ }^{157}$ but only to argue that Rabbat's observation cannot be generalized. Rabbat gave, as a specific example for the representation of mamlüks as speaking colloquial Arabic, a conversation between the amirs Bashtāk al-Nāṣiin̄ (d. 742/1341) and Qawșūn al-Nāṣirī (d. 742/1342) found in al-Șafadī's al-Wäfí bi-l-wafayāt. ${ }^{158}$ It may be mentioned here that these two amirs were Mongols, and there is ample evidence that dur-

154 See above at footnotes $30-7$.

155 Rabbat, Representing $70-5$.

156 It would suffice it here to mention that, as Guo noted, in al-Yūnīnì's DhaylMir'ät al-zamān even the Prophet Muhammad occasionally utters colloquial words, see Guo, Introduction 95. According to Rabbat, whereas mamlūks are represented as speaking colloquial Arabic, the Arab amir Muhannā is represented as speaking grammatically correct Arabic; see Rabbat, Representing 74. However, in the reference given by Rabbat to prove his assertion, it is possible to find several nonstandard usages of Arabic in Muhannā's speech; see al-Yūsufī, Nuzhat 199-207.

157 See Rabbat, Representing 74 (footnote 46).

158 Ibid. $72-4$. 
ing the Turkish period, in contrast to Qipchaqs, Mongols tended not to know Arabic, which contributed to negative attitudes toward them. ${ }^{159}$ More important to the discussion at hand, however, are issues of genre and professional background.

\subsection{Language and Style in the Historical Works of Udabā'-Kuttāb and Language Use in Biographical Dictionaries}

While al-Ṣafadī was a mamlūk's descendant, what seems to be a more important factor is his background as an adīb and kātib. Naturally, udab $\bar{a}^{3}-k u t t a \bar{b} b$ were strongly related to the $a d a b$ tradition. Thus, it would not be surprising to find that historians of such a background were more easily willing to incorporate adab elements in their historical writing. Those of them who produced works pertaining to history that are practically adab works incorporated in these works in a very conspicuous manner nonstandard usages of Arabic and story-like reports or anecdotes with dialogues and direct speech. ${ }^{160}$ In the chronological-historical section of the (adab) encyclopedia Nihāyat alarab, which is much more related to "traditional" Mamluk chronicles, Shihāb al-Dīn al-Nuwayrī (d. 733/1333) incorporated in the account of contemporary events relatively many story-like reports (some very long) with dialogues and direct speech, ${ }^{161}$ although, at least officially, he was affiliated with the Shāfi'i school. Still, it seems that al-Nuwayrī refrained as much as possible from employing nonstandard usages of Arabic (see appendix A group D no. 1), and it may be demonstrated that he systematically standardized nonstandard usages employed in his quoted sources (see appendix B). Biographical dictionaries written by $u d a b \bar{a}-k u t t a \bar{b}$, such as al-Șafadì's al-Wäfí bi-l-wafayāt and A'yān al-'așr and al-Kutubì's (d. 764/1363) Fawāt al-wafayāt, are full of anecdotes or story-like reports containing dialogues with direct speech. Moreover, in the

159 Yosef, Cross-boundary $170-3$.

16o Among these works one may mention Ibn Șașrās (d. after 799/1397) al-Durra al-mudịa (see Brinner, Chronicle, xix-xxv; and see also Blau, State 192; Irwin, Mamluk history 165; and see chapter 1 footnote 14 [(1)]); and al-Nuwayrī al-Iskandarānī's (d. after 775/1373) Kitāb al-Ilmām (see the editor's introduction in al-Nuwayrī al-Iskandarānī, Ilmām iii, 3; and see chapter 1 footnote 14 [(1)]); and al-'Abbāsī al-Ṣafadī’s (d. ca. 717/1317) Nuzhat al-mālik wa-lmamlūk (see the editor's introduction in al-'Abbāsī, Nuzhat 8-14; on al-'Abbāsī al-Ṣafadī's background and on the work's anecdotal nature, see also Krenkow and Little, al-Ṣafadī 759). On the different categories of works pertaining to history written by $u$ dab $\bar{a}$ - $-k u t t a \bar{b}$, see in general chapter 1 footnote 14. On royal biographies written in impeccable Arabic by "court historians" working in the chancery (dīwān al-insh $\bar{a})$ and on typical stylistic elements in these works, see chapter 1 footnote 14 (3).

161 See, for example, al-Nuwayrī, Nihāyat xxxiii, 4, 9-15, 33-5, 38, 48, 140, 150-1. 
frame of the anecdotes or story-like reports that appear in the biographical dictionaries written by al-Kutubī and al-Ṣafadī, one finds many usages of nonstandard Arabic, mostly in dialogues but also outside of dialogues, although the two were officially affiliated to the Shāfi î school. ${ }^{162}$ This is in contrast to Shāfî̀ religious scholars, who produced biographical dictionaries but refrained from nonstandard usages of Arabic also in this genre. ${ }^{163}$ However, it is in line with the usages of Ibn Taghribirdī, the most notable representative of historians related to the military institution, who produced a biographical dictionary. ${ }^{164}$

According to Rabbat, "[t]he puzzling question is why did al-Ṣafadī use ... street vernacular in reporting a conversation between two amirs when his standard conversation language was a more classicizing one?"165 Rabbat, however, is underestimating the amount of nonstandard usages of Arabic in al-Ṣafadì's biographical dictionaries. In the realm of biography, the kingdom of anecdotes and stories, al-Ṣafadī the adīb employed nonstandard usages of Arabic much more than Rabbat would allow. ${ }^{166} \mathrm{He}$ did not only employ it when representing the speech of mamlüks, and even not exclusively in dialogues, but still only in the frame of anecdotes or story-like reports. ${ }^{167}$

\section{Appendix A: Usages of Nonstandard Arabic by Mamluk Historians and Standardization Thereof}

A. Historians related to the military institution (including mamlüks' descendants) employing nonstandard usages of Arabic in a notable degree in their historical writing

\footnotetext{
162 See appendix A group D nos. 2-3.

163 See for example appendix A group D no. 2 (footnote 203); table 2.1 above; and see chapter 1 footnotes $117,175^{-6}$, and 313 .

164 See appendix A group A (mamlüks' descendants no. 3, footnote 178); appendix A group D no. 2 (footnote 203 ); and see table 2.1 above.

165 Rabbat, Representing 74.

166 On style and "literarization" in Mamluk biographical dictionaries, see chapter 1 sections 3 and 4.

167 See appendix A group D no. 2 (footnote 203). While al-Ṣafadī (and other highly educated $u d a b \vec{a}^{\prime}$ ) perhaps had a compunction about quoting purely colloquial genres such as colloquial poetry (see Bauer, Communication 110; Ökzan, Drug 214), he certainly did not mind incorporating in story-like reports some nonstandard usages that draw on colloquial language.
} 


\section{Mamlūks and Soldiers}

1. Qarațāy (d. after 708/1308) ${ }^{168}$

2. Baktāsh al-Fākhirī (d. 745/1344) ${ }^{169}$

3. al-Shujā̄ì (d. after $\left.75^{6 / 1356)}\right)^{170}$

4. al-Yūsufì (d. $\left.759 / 135^{8}\right)^{171}$ [note that al-Șafadī (followed by the Shâfí̄i Ibn Hajar) mentioned that he used colloquial Arabic $]^{172}$

\section{Mamlūks' Descendants (Ignoring al-Ṣafadī Who Belongs More to the adab Tradition)}

1. Ibn al-Dawādārī (d. after $736 / 1335)^{173}$ _ based on an autograph ${ }^{174}$

2. Ibn Duqmāq (d. 8og/1407) ${ }^{175}$ [Hanafì_criticized by the Shāfî̀ İ Ibn Hajar (followed by the Shāfíī al-Sakhāwī) for using colloquial Arabic];: ${ }^{176}$ based on (an edition of) an autograph ${ }^{177}$

3. Ibn Taghrībirdī (d. 874/1470) ${ }^{178}$ [Hanafì-criticized by the Shāfíī alSakhāwī for his less than perfect Arabic (laḥnuhu al-wāḍh $]^{179}$

168 See the editor's introduction in Qarațāy al-'Izzī al-Khaznadārī, Ta’rīkh 11-2; but see Haarmann, Quellenstudien 179; Irwin, Mamluk history 164-5.

169 See the linguistic introduction in Zetterstéen, Beiträge 1-33; al-Fākhirī, Tärīkh 42; and see also Brinner, Chronicle, xx; Blau, State 192; Fück, 'Arabiyya 571.

170 Schäfer, Beiträge 110-5; Chronik 9-14. See also chapter 1 table 1.1 (footnote c); appendix A group E (no. 4, footnotes 211-2); and most importantly see appendix C.

171 Little, Recovery 48; Historiography 426; and see the editor's introduction in al-Yūsufï, Nuzhat 55 .

172 Little, Recovery 48.

173 See the introductions in Haarmann, Kanz 29-38; Roemer, Kanz 21-4; and see also Haarmann, Quellenstudien 176-7, 180; Irwin, Mamluk history 165; Little, Historiography 425, 440; Guo, Introduction 94.

174 Haarmann, Quellenstudien 176.

175 See the editor's introduction in Ibn Duqmāq, Nuzhat 17-8; and see also Haarmann, Joseph's 81; Bauer, Review 26o-2. For examples of usages of nonstandard Arabic in alNafha al-miskiyya (indicated by the editor in footnotes), see Ibn Duqmāq, Naf̣̣a 9o (footnote 9), 91 (footnotes 2, 10), 94 (footnotes 3, 5, 7, 9), 102 (footnote 5), 103 (footnotes 3-4), 144 (footnotes 1-2, 5, 7, 10), 155 (footnote 8), 156 (footnotes 2-7), 161 (footnotes 1, 2, 4, 6$9,13,16), 212$ (footnotes 1-2), 218 (footnotes $7-8,10$ ), 219 (footnote 1), 223 (footnotes 1-2), 224 (footnotes $3,6,8,11-2,15-6$ ); and see also chapter 1 footnote no. 3; and see table 2.1 above.

176 Massoud, Chronicles 28-9; Bauer, Search 153; Review 26o-2; Literarische 105; Ibn Duqmāq, Naf̣̆a 9-10.

177 An autograph of Nuzhat al-anām (Bauer, Review 26o; Ibn Duqmāq, Nuzhat 15), and probably an autograph of al-Nafha al-miskiyya (Ibn Duqmāq, Naf̣̣a 19).

178 See the introduction in al-Biqā̄î̀, Tảrīkh i, 47; and see Muhannā, Ādāb 9; Little, Historiography 440. For examples of usages of nonstandard Arabic in al-Nujüm al-zähira, which normally appear in dialogues or utterances in direct speech in the course of story-like reports or anecdotes (not including references to usages of èsh as interrogative, which 
4. 'Abd al-Bāsiț b. Khalīl b. Shāhīn al-Ẓāhirī al-Malațī (d. 920/1514) ${ }^{180}$ [ب̣an-
afì]; based on (an edition of) an autograph (draft?)

appear in many dialogues and seem to function as a marker of discourse in the spoken language), see Ibn Taghrībirdī, Nujūm xii, 88 (as jawāb al-amr, the verb tastarịhu appears in the indicative instead of the jussive, or alternatively tastarị with a long vowel in the final closed syllable; see on that Blau, Handbook 30 [no. 6]; Lentin, Levant 186; Brinner, Chronicle, xxiv; Zetterstéen, Beiträge 28; Haarmann, Kanz 36 ); and see Ibn Taghrībirdī, Nujūm xiii, 83 (“anā mā qultu laka anā a'rifu Shaykh?"; Did not I told you I know Shaykh?: asyndetic object clause and repetition of pronouns, which is typical of colloquial language; see Blau, Handbook 52-3 [no. 128]; Haarmann, Kanz 36); and see Ibn Taghrībirdī, Nujūm xiii, 140; xv, 413 (verbs in the indicative in plural masculine form end without $n$ [yatawajjahū and not yatawajjahūna; yaḥ̂urū and not yahḍurūna], and see Blau, Handbook 45 [no. 77]); and see Ibn Taghrībirdī, Nujūm xiv, 193; xv, 46, 237 (colloquial biyif'al, bitut'ib, biyirkab - usages of the $b$-imperfect; see on that Zetterstéen, Beiträge 28; Haarmann, Kanz 38; Brinner, Chronicle, xx [footnote 44]; Vrolijk, Bringing 155-6; Lentin, Levant 187-91); and see Ibn Taghrībirdī, Nujūm xv, $5^{6}$ (line 11: lā in the meaning of "lest" instead of the standard li-allā; such a $\bar{l} \overline{\text { is }}$ attested in Middle Arabic, see Blau, Dictionary 619; and in Mamluk historiographical texts, see Haarmann, Kanz 37); and see Ibn Taghrībirdī, Nujūm xv, 531 ("ya'tī wähid min hä̉ulä’i al-jahala yamsiku kitāb fì l-figh," one of these ignorants comes [and] takes a book of law: omission of the conjunction and absence of the accusative alif in the object kitäb; on the absence of the accusative alif in Middle Arabic, see Blau, Handbook 44 [no. 74]; on the omission of conjunctions in Mamluk historiographical texts, see Zetterstéen, Beiträge 32; Haarmann, Kanz 37). And see also chapter 1 footnote 4. It is noteworthy that in al-Manhal al-șâfi, Ibn Taghribirdì preserves some of the nonstandard usages in reports he is quoting from al-Ṣafadī; see appendix A group D, no. 2, footnote 203 below; and see table 2.1 above. Apparently, he also keeps nonstandard usages from Ibn Duqmāq's Nuzhat al-anām; see table 2.1 above. For another example of a usage of nonstandard Arabic in a dialouge in al-Manhal al-șăfí, see Ibn Taghrībirdī, Manhal iii, 380 (absence of accusative alif: "lā takun șabü").

179 Al-Sakhāwī, Daw ${ }^{3}$ x, 307; and see also Haarmann, Arabic 113; and see Rabbat, Representing 70 (footnote 32 ).

180 As far as I know, the language in al-Malațîs historical works did not receive attention; however, the editor's footnotes in the edition of al-Rawd al-bāsim often refer to nonstandard usages of Arabic. For conspicuous examples of usages of nonstandard Arabic in al-Raw ḍ al-bāsim, many times found in personal reports or story-like reports containing dialogues and direct speech, see al-Malațī, Raw d i, 168 (footnote 3), 169 (footnote 3), 181 (footnote 2), 199 (footnotes 4-5), 23 (footnote 6), 288 (footnote 2), 319 (footnote 2), 323 (footnote 3), 347 (footnote 4), 382 (footnote 2); ii, 69 (footnotes 3-4), 71 (footnotes 4-5), 87 (footnotes 2-3), 104 (footnotes 1, 4, 6, 8), 114 (footnote 9), 119 (footnote 1), 147 (footnote 2), 153 (footnote 3), 177 (footnote 1), 183 (footnote 2), 186 (footnote 3), 187 (footnotes 1, 5), 223 (footnotes 1-2), 229 (footnote 5), 23 (footnotes 1, 4-5, 7), 233 (footnote 1), 234 (footnotes 1-2), 238 (footnote 5), 239 (footnote 2), 262 (footnote 1), 264 (footnote 2), 265 (footnote 3 ), 267 (footnote 2), 268 (footnote 3), 276 (footnotes 3, 5), 287 (footnote 10), 292 (footnotes 7-8), 293 (footnotes 1-6, 8), 294 (footnotes 1, 3), 295 (footnotes 1-2), 300 (footnote 9), 315 (footnotes 5, 8), 324 (footnote 2), 335 (footnote 1), 336 (footnote 2), 341 (footnote 4), 342 (footnotes 3, 4, 6), 343 (footnote 3), 350 (footnotes 3, 5), 368 (footnote 5), 372 (footnotes 2, 6, 7), 375 (footnote 1), 376 (footnotes 1, 4); iii, 30 (footnotes 3, 7), 102 (footnote 6), 117 
5. Ibn Iyās (d. ca. 930/1524) ${ }^{182}$ [Ḥanafi]]; based on an autograph ${ }^{183}$

***Exception: Baybars al-Manșūrī al-Dawādār (d. 725/1325)

\section{B. Hanafi religious scholars employing nonstandard usages of Arabic in a not- able degree in their historical writing}

1. Ibn al-Furāt (d. 807/1405) $)^{185}$ [criticized by the Shāfici al-Sakhāwī for his colloquial style and lack of knowledge of Arabic grammar];186 based on (an edition of) an autograph draft ${ }^{187}$

2. [much less conspicuously] al-'Aynī (d. 855/1451) [while normally transforming al-Yūsufi's colloquial usages into standard Arabic, ${ }^{188}$ accused by the Shāfici Ibn Ḥajar of quoting Ibn Duqmāq without correcting his linguistic mistakes];189 partially based on (an edition of) an autograph

(footnotes 1-4), 193 (footnote 1), 201 (footnote 1), 207 (footnote 6), 209 (footnote 1), 210 (footnotes 1-2), 211 (footnote 3), 212 (footnote 2), 291 (footnote 5), 292 (footnote 1), 293 (footnotes 1-2), 296 (footnote 2), 336 (footnote 3), 337 (footnote 2), 338 (footnotes 1, 3, 5), 340 (footnotes 4, 6); iv, 44 (footnotes 1-2), 45 (footnote 1), 48 (footnotes 4, 6), 96 (footnotes 2, 4), 97 (footnotes 1-2). And see also footnote 4 above; and see chapter 1 footnote 5 .

181 Petry, Protectors 7; al-Malațī, Raw ḍ i, 79-83 (esp. 82).

182 Kahle, Einleitung 26-8; Guo, Mamluk 41-3; and see also Blau, State 192; Rizq Salīm, Adab 21; 'Āṭif et al., Adabiyyāt 26; Fück, 'Arabiyya 571; Havemann, Chronicle of Ibn Iyās 89; Muhannā, Ādāb 9; Little, Historiography 440; Massoud, Chronicles 75-6.

183 Kahle, Einleitung 3.

184 As a dawādār and chief of the chancery, he was related to the insh $\bar{a}$ tradition, which favors ornamented language, poetry, and rhymed prose in impeccable Arabic. On Baybars alManșūī al-Dawādār, see for example Irwin, Mamluk history 163; Little, Historiography 423-4.

185 Brinner, Chronicle, xx; and see also Bora, Mamluk 119. Brinner and Bora make a general assessment of Ibn al-Furāt's language without going into detail (Brinner gives one example for a usage of nonstandard Arabic, and Bora gives no examples). For examples of usages of nonstandard Arabic in Ibn al-Furāt's chronicle, which were standardized by al-Maqrīzī, see chapter 1 footnote 48 .

186 Irwin, Mamluk history 166; Cahen, Ibn al-Furāt 768-9; Bora, Mamluk 121-2.

187 Ibid. 124-5.

188 Little, Recovery 44; An analysis 26o; see, however, al-Aynī, Iqd, ed. Amīn iv, 67 (in a story-like report with dialogues in direct speech quoted from al-Yūsufĩ and labeled as a "strange" occurrence [min al-'ajāi ib], al-'Aynī employs the colloquial jāba in the meaning of "brought"; on jāba, see Guo, Commerce 132). In another story-like report quoted from alYūsufì, al-'Aynī employs an asyndetic subordinate clause ("esh aqdiru a'malu," what can I do?) and omits a conjunction ("taqaddam ughïru anā wa-anta," step forward and you and I will fight—note also the peculiar usage of the verb aghāra); see al-Aynī, Iqd, ed. Amīn iv, 68. For an asyndetic object clause, see also ibid. iv, 125 ("tastahūna [...] tatahaddathüna").

189 Bauer, Review 26o. According to 'Abd al-Razzāq al-Ṭanțāwī al-Qarmūț, who edited the years 824-50/1421-47 in Iqd al-jumān based on an autograph, except for minor and mainly 


\section{Ibn al-Ṣayrafì (d. 9oo/1495) ${ }^{190}$ [the Shāfí̄ al-Sakhāwī hinted in criticism that he used colloquial Arabic];191 partially based on an autograph ${ }^{192}$}

hamza-related orthographical deviations that became the norm by the Mamluk period, al-Aynī refrained from using "vulgar expressions" (alfäz khashina); however, due to lack of attention, one may find few such expressions in his autograph; see al-'Aynī, Iqd, ed. al-Qarmūt 46, 54. İmān 'Umar Shukrī who edited the years 784-801/1382-98 in Iqd aljumān, in which al-Aynī may have relied on Nuzhat al-anām (see Massoud, Chronicles 40, 109-10 [note that the relevant parts from Nuzhat al-anām are not extant]), mentions that al-'Aynī constantly uses the verb akhla'a ('alā) in the fourth verbal theme in the meaning of "bestowed" instead of the standard khala'a in the first verbal theme; see al-'Aynī, Sulțān Barqūq 136 (footnote 105). Al-'Aynī also sometimes employs the plural instead of the dual; see ibid. 149, 157 (footnote 43). Al-'Aynī sometimes omits the accusative alif in proper nouns; see ibid. 162, 167 (footnote 9). Alternatively, he adds accusative alif in cases in which in standard Arabic the accusative alif would not have been added; see ibid. 214, 218 (footnote 8). Al-'Aynī sometimes employs the ending- $\bar{u}$ in $a b \bar{u}$ where the ending $-\bar{l}$ should have been used in standard Arabic; see ibid. 226, 230 (footnote 24). On usages of the fourth verbal theme instead of the first verbal theme in Middle Arabic, see Blau, Handbook 38 (no. 40); on the phenomenon in Mamluk historiographical texts and specifically on akhla'a instead of khala'a, see Zetterstéen, Beiträge 2. On plural forms superseding dual forms in Middle Arabic, see Blau, Handbook 42 (no. 59). On the absence of the accusative alif or its improper addition, and on the prevalence of the ending $-\bar{u}$ in $a b \bar{u}$ in Middle Arabic, see ibid. 44 (no. 74). Only further research, especially on earlier years in Iqd al-jumān where reliance on Ibn Duqmāq's Nuzhat al-anām has been established (see Massoud, Chronicles 40), will enable us to determine if Ibn Hajar's accusations are correct and to what degree al-Aynī was willing to employ nonstandard usages of Arabic and if such usages were the result of lack of attention. The relevant parts of Iqd al-jumān and Nuzhat al-anām (the extant years are $768-79 / 1366-$ 78 ) are still in manuscript form and have not been consulted by the author of this article. Interestingly, however, according to Massoud, who compared the accounts of the year 778/1376-7 in Nuzhat al-anām and Iqd al-jumān, "[f]or the year 778 ... Iqd aljumān ... is but a mere replica of Nuzhat al-anām. Sometimes al-'Aynī takes liberty with the text, as he moves, adds and/or changes generally small narrative elements within given reports. More often than not, however, he simply copies word-for-word, adds or removes words here and there, or introduces very slight changes"; see Massoud, Chronicles 40. Moreover, in the two short passages (three and four lines, respectively) from Nuzhat al-anām, which Massoud gives word-for-word in order to exemplify al-'Aynī's reliance on it, al-'Ayni's text preserves a nonstandard usage that appears in Nuzhat alanām: "fa-sāra ilayhim jamā'a" (lack of gender concord, standard: fa-sārat) and adds a nonstandard usage (a mistake?) of his own: "kāna qarīb" (standard: kāna qarīban); see ibid. 40, 44-5. On the lack of gender concord in Middle Arabic, see Blau, Handbook 46 (no. 82).

190 See the editor's introductions in Ibn al-Ṣayrafī, Nuzhat i, 6-7; Inb $\bar{a}^{3}$ 19-20; and see also Petry, Scholastic 334; Protectors 6; Massoud, Chronicles 134.

191 Massoud, Chronicles 134.

192 Ibn al-Ṣayrafì, Nuzhat i, 9-10. 
4. Ibn Ṭūūn (d. 953/1546) ${ }^{193}$ [criticized by the Shāfíì Mūsā b. Yūsuf alAyyūbī al-Anșārī (d. 1000/1592) for incorporating colloquial expressions in his writing], ${ }^{194}$ based on an autograph ${ }^{195}$

C. Ḥanbalī (-milieu) religious scholars employing nonstandard usages of Arabic in a notable degree in their historical writing

1. al-Yūnīnī (d. 726/1326) $)^{196}$

2. al-Jazarī (d. 739/1338) ${ }^{197}$ [criticized by the Shāfíī al-Dhahabī for using colloquial Arabic];198 based on an autograph ${ }^{199}$

****Exception?: [much less conspicuously, if at all] al-Birzālī (d. 739/1339) ${ }^{200}$

193 See Hartmann, Tübinger 103-4; and see also Fück, 'Arabiyya 571; and see the editor's introduction in Ibn Ṭūlūn, I'lām 16.

194 See Ībish, Ta'rīkh 78; and see also Hartmann, Tübinger 103.

195 İbish, Ta'rīkh 70.

196 Guo, Introduction 94-6.

197 Haarmann, Quellenstudien 176-7, 180; Guo, Introduction 94-6; Little, Historiography 4289; Lentin, Levant 179, 183, 186-7, 189, 197; and see appendix B.

198 Haarmann, Kanz 27.

199 Ibid., Quellenstudien 176.

200 Guo suggested that it is worthwhile considering that the trend of the "increasing use of colloquial in the historical narrative during the Mamluk period" has actually started in Syria at the hands of al-Jazarī, al-Yūnīnī, and al-Birzālī; see Guo, Introduction 94; however, while usages of nonstandard Arabic by al-Jazarī (Haarmann) and al-Yūnīnī (Guo) has been noted and partially documented (see appendix A group C nos. 1-2), usages of nonstandard Arabic in the chronicle of al-Birzālī have not received much attention. Tadmurī, the editor of al-Birzālī's chronicle, noted that its language is generally clean of deviations from standard Arabic (ammà lughat al-makhțūt fa-hiya salìma ilä ḥadd kabīr), and he mentions only deviations related to orthography and morphology of numerals that, according to Tadmurī, are typical of historical works during the Mamluk period; see al-Birzālī, Muqtafi i, 119. While it is clear that the deviations in al-Birzālī's chronicle are much less conspicuous and more minor in comparison to his Syrian Hanbalī colleagues, there are some deviations that are not restricted to orthography or related to numerals. This observation is based on a survey of remarks of Tadmuri in footnotes in the third and fourth volumes of al-Muqtafi regarding al-Birzāli’s deviations from standard Arabic (the standard form is given by Tadmurī in the footnotes); see, for example, al-Birzālī, Muqtafı iii, 213 (footnote 4), 214 (footnote 2); iv, 21 (footnote 3), 30 (footnote 6), 66 (footnotes 1, 3), 85 (footnote 7), 202 (footnote 3), 239 (footnote 5), 247 (footnote 2), 305 (footnote 3), 306 (footnote 7 ), 322 (footnote 2), 36o (footnote 1), 379 (footnote 1), 436 (footnote 2), 439 (footnote 2 ), 440 (footnotes 2, 7-8), 455 (footnote 2). While it is possible that the deviations from standard Arabic in al-Birzālī are more conspicuous than the deviations that can be found in chronicles written by Shāfiī religious scholars, it may well be argued that in al-Birzālī's case, the relatively minor deviations are also the result of lack of attention. Still, the relatively low 


\section{Historians related to the $u d a b \bar{a}^{\prime}-k u t t a \bar{b} b$ tradition}

\section{It seems that at least those of them who wrote biographical dictionaries did not refrain from employing nonstandard Arabic, notably within anecdotes or story-like reports combining dialogues with direct speech. ${ }^{201}$ The ones checked are all officially Shāfīîs:}

1. al-Nuwayrī (d. $733 / 1333)^{202}$

number of deviations in al-Birzālī's chronicle may be partially explained by its "dry" nature and almost total absence of 'ajāi ib and story-like reports with dialogues employing direct speech; see chapter 1 footnote 12. In fact, in the rare cases that al-Birzāli mentions strange phenomena or story-like reports, the number of deviations from standard Arabic seems to be higher, and they are not restricted to orthography. For example, in a description of a weird animal that appeared in the Nile, al-Birzāli refers to its ears that look like the ears of a camel in the plural (wa-ādhānuhā ka-ādhān al-jamal) instead of the grammatically correct form of the dual $(u d h n \bar{a} h \bar{a})$. He mentions that it had four fangs and refers to their length in the plural form (tüluhum) instead of the grammatically correct form of the feminine $(t \bar{u} l u h \bar{a})$. He also mentions that the animal had three stomachs, using the masculine numeral (thaläth) instead of the grammatically correct feminine numeral (thalätha), see al-Birzālī, Muqtafi iii, 213-4. On plural forms superseding dual forms in Middle Arabic, see Blau, Handbook 42 (no. 59). On plurals/nouns not denoting persons referred to as plurals in Middle Arabic, see ibid. 45 (no. 8o). Interestingly, the Shāfi'ì religious scholar Ibn Kathīr (d. 774/1373), who quotes al-Birzālī's report, standardizes all the abovementioned deviations from standard Arabic; see Ibn Kathīr, Bidāya xiv, 26. Another story-like report in the chronicle of al-Birzāli about a strong wind that devastated a settlement of Turkmens employs direct speech with the nonstandard $\bar{e} s$ and the nonstandard plural ajmäl instead of the standard jimāl for "camels"; see al-Birzālī, Muqtafi iv, 306. On the plural af'äl in Middle Arabic instead of the standard fical, see Blau, Handbook 42 (no. 64); on ajmäl in Mamluk texts, see al-'Abbāsī, Nuzhat 14. The Shāfi'ī Ibn Kathīr condenses the report and omits the direct speech with the nonstandard èsh and employs the standard plural jimāl; see Ibn Kathīr, Bidāya xiv, 99. This would seem to suggest that although not much inclined to deviate from standard Arabic, al-Birzālī, in contrast to his Shāfici peers, did not object to that in principle. For another story-like report in al-Birzālī with three deviations from standard Arabic, see al-Birzālī, Muqtafì iv, 353 (footnotes 1-3); and see perhaps also ibid. iv, 440 (footnotes 2, 7, 8), 441 (footnotes 1-2).

201 I do not include here authors who produced works pertaining to history that are practically adab works, which employ nonstandard Arabic in a conspicuous manner; see at footnote 16 o above.

202 Nonstandard usages in Nihāyat al-arab are apparently very rare. As mentioned, al-Birzālī uses in a report the nonstandard plural ajmäl instead of the standard jimäl for "camels." The Shāfīi religious scholar Ibn Kathīr, who quotes al-Birzālī, employs the standard plural jimāl; see footnote 200 above. In al-Nuwayrì's report, the nonstandard plural ajmāl is employed; see al-Nuwayrī, Nihāyat xxxii, 219-20. Al-Nuwayrī does not quote his source, but he is known to have relied on al-Jazarī; see Little, Introduction 30-2. For another rare example of usages of nonstandard Arabic, see al-Nuwayrī, Nihāyat xxix, 307-8 (in the course of a hikāya with dialogues and direct speech, quoted from al-Yūnīnī). More commonly we find cases in which al-Nuwayrī consistently standardized nonstandard usages of Arabic in al-Jazarī's reports; see appendix B. It would seem that al-Nuwayrī was much 
2. al-Ṣafadī (d. $764 / 1363)^{203}$ —based on (an edition of) manuscripts, parts of which are autograph ${ }^{204}$

less inclined (if at all) to incorporate nonstandard usages of Arabic in his writing than the two next representatives of the $u d a b \bar{a}^{2}-k u t t a \bar{b}$. This, however, should be examined further.

203 Just for example, in the biographical entry of the shaykh 'Abd al-Ghanī b. 'Urwa al-Ra's 'Aynī (d. 718/1318), after a short life résumé and a general description of about six lines, al-Ṣafadì dedicates the rest of the entry (about two and a half pages) to entertaining stories, which 'Abd al-Ghanī used to tell (kāna kathïran mā yaḥkī) about his happenings with members of the elite, that are full of dialogues in direct speech and bear unmistakable marks of colloquial language. In the anecdotes, we find the nonclassical or colloquial verb darwaza in the meaning of "begged for money," the colloquial wali in the meaning of "woe unto me!" instead of the standard wayl li, and the conjunction wa-illa in the meaning of "or," reflecting the colloquial wallā instead of the standard am. Except for the customary $\bar{e} s h$, we also find lèsh (why?) instead of the standard li-mādhā. In addition, we find the nonstandard imperative rūh (go!) instead of the standard ruh (or rather idhhab-while the verb rāha is found in dictionaries of Classical Arabic, it is much more common in the colloquial language). There is also a verbal temporal clause that appears after the word ayyām ("ayyām ishtarā," in the days when he bought); see al-Ṣafadī, A'yān iii, 115-8. On the verb darwaza, see Taymūr, Mújam iii, 262; on walī, see 'Abd al-Raḥīm, Mawsū'at iii, 26o3; on wallā in modern Egyptian, see Badawi and Hinds, Dictionary 956; on wallā used alongside willa in a 9th/15th-century Mamluk literary text, see Vrolijk, Bringing 155; on lessh in Middle Arabic, see Blau, Dictionary 644; in a 9th/15th-century literary text, see Vrolijk, Bringing 154. On yawm opening a verbal temporal clause, see Haarmann, Kanz 37. In the biographical entry of the merchant Tawba b. 'Alī al-Takrītī, al-Ṣafadī incorporates an entertaining story with a dialogue in direct speech involving a drugged person (masțül一a "post-classical" word) that employs bad language. In this story it is possible to find the word wăhid used as an indefinite article, the Egyptian colloquial ablam in the meaning of "stupid," and of course the customary ēsh, see al-Ṣafadī, Wāf $\iota$ x, 439; A'yān ii, 140. On masțūl and ablam, see Taymūr, Mujam ii, 225; iii, 112; on wāhid as an indefinite article in Middle Arabic, see Blau, Dictionary 754; for another example of such a usage of wāhid in A'yān al-'așr, see al-Ṣafadī, Áyān ii, 122. In the biographical entry of Baktamur al-Sāqī (d. 733/ 1333) in al-Ṣafadī's biographical dictionaries there are many anecdotes or story-like reports that employ direct speech and nonstandard language. We find $\bar{e} s h$ and $\bar{l} \bar{s} h$, the colloquial bass (stop), and the nonstandard imperatives rüḥ and būs (kiss!); see, Wāfì x, 195-6; Aýān i, 712-4. On bass see, Haarmann, Kanz 38; and see also Vrolijk, Bringing 155. For further examples, see Lentin, Levant 189. In his biographical dictionary al-Durar al-kämina dedicated to important people who died in the 8th/14th century, Ibn Ḥajar relies heavily on al-Ṣafadī; see Little, Introduction 106-8. It is noteworthy that Ibn Hajar gets rid of practically all the nonstandard usages of al-Ṣafadī. Normally he does this by omitting or heavily condensing the anecdotes, turning them into bare statements of fact (on the condensing of reports, see ibid. 107). For example, the biographical entry of 'Abd al-Ghanī b. 'Urwa al-Ra's 'Aynī is reduced in al-Durar al-kāmina to four lines of a short life résumé and general description, clearly based on that of alȘafadī. Ibn Hajar omits the two and a half pages of anecdotes with dialogues, including direct speech and nonstandard Arabic that appear in al-Ṣafadī; see Ibn Ḥajar, Durar ii, 388 . In another biographical entry, al-Ṣafadī gives a story-like report told to him by the subject of the biographical entry $(h a k \bar{a})$, which employs the nonstandard imperative $q \bar{u} l$ in direct speech (see al-Ṣafadī, $A^{\prime} y \bar{a} n \mathrm{v},{ }_{563}$ ). Ibn Ḥajar transforms the anecdote into a statement of 
3. $\quad$ al-Kutubī (d. $764 / 1363)^{205}$

\section{E. Shāfíi religious scholars that refrained from using nonstandard Arabic (at least in any significant manner)}

1. al-Dhahabī (d. 748/1348)—standardized al-Jazarī, for example ${ }^{206}$ [criticized al-Jazari’s non-standard usages]; ${ }^{207}$ based on (an edition of) an autograph $^{208}$

fact in reported speech and totally changes the wording; see Ibn Ḥajar, Durar iv, 416-7. In other cases, Ibn Hajar does not include in his dictionary the biographical entry (such is the case with Tawba b. 'Alī al-Takrīīī). In relatively few cases, however, Ibn Ḥajar preserves sentences in direct speech, and in such cases one may find direct standardizing of al-Ṣafadì's text. For example, in the biographical entry of Baktamur al-Sāqī, Ibn Ḥajar omits almost all anecdotes and story-like reports or heavily transforms their wording. Still, one may find a few short sentences in direct speech taken from the anecdotes in al-Ṣafadī. Al-Ṣafadī's text has "rūḥ ilā al-amīr [wa-]büs yadahu" (go to the amir [and] kiss his hand); see alȘafadī, Wāfi x, 195 (no conjunctive); Áyān i, 714 (with conjunctive). Ibn Ḥajar standardizes the imperative forms and follows the version with the conjunctive from A'yān al-'așr"ruḥ ilā al-amìr wa-bus yadahu"; see Ibn Ḥajar, Durar i, 486; and see table 2.1 above. It is also worthwhile to compare the practice of Ibn Hajar with that of Ibn Taghrībirdī in al-Manhal al-șâfi, who preserves many more anecdotes from al-Ṣafadī and does not omit all nonstandard usages. For example, in the biographical entry of the abovementioned Tawba b. 'Alī al-Takrīiti, while Ibn Taghrïbirdī omits the word ablam (perhaps because he wanted to keep a clean language), he preserves the word masțull, the èsh, and the nonstandard usage of wāhid as an indefinite article; see Ibn Taghrībirdī, Manhal iv, 18o. In the biographical entry of Baktamur al-Sāqī, Ibn Taghrïbirdī preserves many of the sentences in direct speech that appear in al-Ṣafadī. The lēsh in al-Ṣafadī's report becomes an èsh; however, Ibn Taghrībirdī preserves the colloquial bass, and has "rūḥ ilā al-amìr būs yadahu" with no conjunctive (i.e., the version from al-Wäfi ); see ibid. iii, 393-6 (esp. 393); and see table 2.1 above. On Ibn Taghrïbirdì's reliance in al-Manhal al-șăfi on al-Ṣafadī, see Little, Introduction 108; and see chapter 1 at footnote 133 and chapter 1 appendix A.

204 See the editors' introductions in al-Ṣafadī, Wāf $\iota$ i, i-iii; A'yān i, 25-6.

205 Just for example, in the biographical entry of the abovementioned Tawba b. 'Alī al-Takrīit (see footnote 203 above), al-Kutubī uses the vulgar qawwād (pimp) instead of ablam that appears in al-Ṣafadī and employs the word masțūl and the essh. He also employs in the anecdote the nonstandard form of the imperative $q \bar{u} l$ instead of the standard qul. AlKutubī also gives in the biographical entry an entertaining anecdote with a dialogue full of sentences in direct speech, which does not appear in al-Ṣafadī. In this anecdote, we find nonstandard imperatives such as qūl and rüh, circumstantial adverbs with no accusative alif (bāki instead of the standard bākiyan), and asyndetic object clauses whose object appears without accusative alif ("ta'rifu ta'kulu aruzz?"; [do] you know how to eat rice?, instead of the standard “[hal] ta'rifu an ta'kula aruzzan?"); see al-Kutubī, Fawāt i, 261-2. For further examples, see Lentin, Levant 184, 189.

206 See appendix B. On al-Dhahabī's reliance on al-Jazarī, see Little, Introduction 63.

207 See footnote 198 above.

208 See the editor's introduction in al-Dhahabī, Ta'rīkh i, 7-8. 
2. Ibn Kathīr (d. 774/1373) — standardized al-Birzālī, for example 209

3. al-Maqrīzī (d. 845/1442) — standardized al-Yūsufī and Ibn al-Furāt, for example; ${ }^{210}$ partially based on (editions of) autographs

4. Ibn Qāọī Shuhba (d. 851/1448)—standardized al-Shujāīì, for example; ;11 based on an edition of a manuscript copied by Ibn Qāḍi Shuhba's student, but probably corrected and approved by Ibn Qāọī Shuhba ${ }^{212}$

5. Ibn Ḥajar al-'Asqalānī (d. 852/1449)—standardized al-Ṣafadī, for example $^{213}$ [criticized al-Yūsufî, Ibn Duqmāq, and al-'Aynī]; ;14 based on (an edition) of a manuscript in the hand of al-Sakhāwī that was corrected by Ibn Hajar 215

6. al-Biqā̄i $\overline{\mathbf{i}}^{\mathrm{i}}$ (d. 885/148o $)^{216}$ _based on an autograph draft $^{217}$

7. al-Sakhāwī (d. 902/1497) [criticized Ibn al-Furāt, Ibn Duqmāq, Ibn Taghrībirdī, and Ibn al-Ṣayrafī] $]^{218}$

***Exception: Abū Ḥāmid al-Maqdisī (d. 888/1483) 219

209 See footnote 200 above.

210 See chapter 1 table 1.2 and footnote 48 ; and see also table 2.1 above.

211 See appendix C. On Ibn Qāḍī Shuhba's reliance on al-Shujāīì, see Schäfer, Chronik 3-4.

212 See the editor's introduction in Ibn Qāḍi Shuhba, Ta’rīkh ii, 57-61, 69-73. It should be noted that when it is possible to compare the student's copy (al-'Ajlūnī) with an autograph manuscript of the chronicle covering the years $781-808 / 1379-1406$, it is possible to find many instances in which al-'Ajlūnì standardized the language of the autograph manuscript. However, such cases are found only in parts of the manuscript that were clearly still a draft. These parts of the autograph draft were written quickly and probably contained word-for-word quotations of sources used by Ibn Qāḍī Shuhba, including its original nonstandard usages of Arabic. Given the fact that Ibn Qāọi Shuhba corrected his student's copy and approved it, it is very reasonable to assume that his student actually participated in the process of transforming Ibn Qāḍī Shuhba's draft into a fair copy.

213 See footnote 203 above; and see table 2.1 above.

214 See footnotes 172, 176, 189 above.

215 Ibn Hajar, Durar i, 3.

216 On the language in his autograph draft, see al-Biqāì̄, Ta'rīkh i, 47.

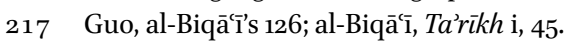

218 See footnotes $176,179,186,191$ above.

219 On nonstandard usages of Arabic in his Kitāb Duwal al-Islām al-sharīfa al-bahiyya, see Haarmann's introduction in al-Maqdisī, Duwal 32-3; on nonstandard usages of Arabic in his Ta'rīkh al-Malik al-Ashraf Qāytbāy, see Tadmurī's introduction in al-Maqdisī, Ta'rīkh 1o; and see also Haarmann, al-Maqrīzī 156-7. 


\section{Appendix B: Standardization of al-Jazarī by al-Nuwayrī and al-Dhahabī (the Story of the Murder of al-Ashraf Khalīl) ${ }^{220}$}

The text in black is al-Jazarīs Hawādith al-zamān, ${ }^{221}$ the text in purple is al-Dhahabī's al-Mukhtār min Tärīkh Ibn al-Jazarī,222 the text in green is alDhahabī's Ta'rīkh al-Isläm, ${ }^{223}$ and the text in red is al-Nuwayri's Nihāyat alarab. ${ }^{224}$ The instances of nonstandard usages of Arabic and its standardization are in orange color and preceded by blue numerals in brackets. The standardization in Ta'rīkh al-Islām or Nihāyat al-arab is sometimes direct (see nos. 2, 3, 5, 7, 9-11, 13-7); however, at other times the nonstandard usage of al-Jazari is avoided by its omission (see nos. 1, 12-3, 17), or by paraphrasing the author's text (see nos. 3, 7-8, 14). Because al-Nuwayrì's standardization is sometimes very different from that of al-Dhahabī, it is relatively clear that al-Nuwayrīs text is not dependent on that of al-Dhahabì (see nos. 3, 6-7, 13-4). This is also suggested by cases in which al-Nuwayri's text reproduces al-Jazarìs wording, whereas al-Dhahabī omits parts of it (see before nos. 12-4, after no. 14, and before no. 15). Note that only the most conspicuous instances of usages of nonstandard Arabic were marked in orange color (and see the editor's footnotes in al-Jazari's text regarding nonstandard usages of Arabic in this text and its standard form). I have reproduced the orthography of the printed editions, and orthographical deviations from standard Arabic are ignored. In addition, only the relevant parts are vocalized, and the text is not translated. I have only made brief comments in footnotes on the nonstandard usages because the purpose of this appendix is to illustrate a process of standardization and not analyze the linguistic peculiarities of al-Jazari's text. Note that there is one case in which alDhahabī fails to standardize al-Jazarì's text (no. 2). This must be due to lack of attention since it is clear in this text, and in other cases where it is possible to compare between Ta'rīkh al-Isläm and Hawādith al-zamān, that al-Dhahabī put great efforts in standardizing al-Jazari’s text. ${ }^{225}$

220 The historians refer to the report as a "story" (hikāya), use the verb hakā in relation to the act of the transmission of the report by the informant, and call the informant al-hākī; see al-Jazarī, Ta'rīkh i, 209 (line 7); al-Dhahabī, al-Mukhtār 361 (line 12); al-Nuwayrī, Nihāyat xxxi, 164 (lines $3,19-20$ ).

221 Al-Jazarī, Ta'rīkh i, 209-10.

222 Al-Dhahabī, al-Mukhtār 362.

223 Ibid., Ta’rīkh lii, 183. Al-Dhahabī mentions al-Jazarī as the source of his report, see lii, 182.

224 Al-Nuwayrī, Nihāyat xxxi, 164. Al-Nuwayrī does not mention the name of al-Jazarī as a source, however, he is known to have relied on al-Jazarī; see Little, Introduction $30-2$. Note that al-Nuwayrī cuts the end of al-Jazarī's report.

225 Compare, for example, al-Jazarī, Ta’rīkh i, 192 (line 13)-193 (line 15) (and see the editor's 
Al-Mukhtār min Ta'rīkh Ibn al-Jazarī is a selection of reports from al-Jazarī's chronicle collected by al-Dhahabī. It is extant in an autograph manuscript. ${ }^{226}$ Such collections were used by the authors as raw material and were not meant to be published. Many times, the reports selected were copied almost wordfor-word. Some of the material in the selections was later incorporated into the historical works, however, only after additional revision (at least in the case of some authors). As can be seen, although the process of transforming the wording of al-Jazarīs text and standardizing it is already noticeable in al-Mukhtār, it is clear that al-Dhahabī did not aim at totally standardizing al-Jazarīs reports in the initial stage of collecting them. In some cases, the original wording of al-Jazarī is preserved, including nonstandard usages of Arabic (see nos. 2, 3, $7,13) .{ }^{227}$ Such nonstandard usages in al-Mukhtār were later standardized in Tärïkh al-Isläm (except for no. 2). ${ }^{228}$ In other cases, it is clear that the wording of al-Mukhtār is closer to al-Jazari’s original text than Ta'rīkh al-Islām; however, nonstandard usages of Arabic are not involved. Such instances are written in bold font (see between nos. 1 and 2, before no. 10, after no. 13, before nos. 14 and 15, and after no. 17).

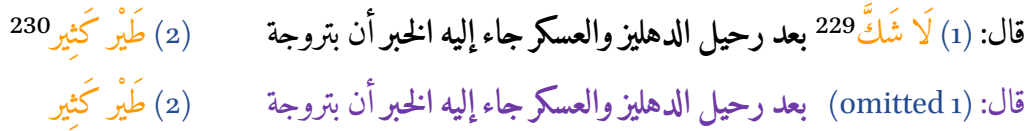

footnotes regarding nonstandard usages of Arabic and its standard form), with alDhahabī, Ta'rīkh lii, 182 (line 9)-183 (line 9), and with al-Mukhtār 361 (line 12)-362 (line 9), and also with al-Nuwayrī, Nihāyat xxxi, 166 (all the page). Compare also al-Jazarī, Ta'rīkh i, 191 (line 7)-192 (line 12) (and see the editor's footnotes regarding nonstandard usages of Arabic and its standard form), with al-Dhahabī, Ta'rīkh lii, 181 (line 11)-182 (line 8), and with al-Mukhtār 36o (line 12)-361 (line 11). For comparison of texts that appear only in Nihāyat al-arab and Hawādith al-zamān, see, for example, al-Jazarī, Tärīkh i, 279-80 (esp. 28o footnote 1), and compare with al-Nuwayrī, Nihāyat xxxi, 186-7 (esp. 187 line 4).

226 See the editor's introduction in al-Dhahabī, al-Mukhtār $5^{2-3}$.

227 And see the editor's remark that al-Mukhtär contains nonstandard usages of Arabic (alalfāz wa-l-mufradāt al-'āmmiyya), see ibid. 53 .

228 For other examples of nonstandard usages of Arabic in al-Jazarīs chronicle, which found their way into al-Mukhtār but later on were standardized in Tärīkh al-Islām, see al-Jazarī, Tärīkh i, 44 (line 16: "lā takūn sabab halāk al-Muslimina" - a long vowel in a final closed syllable), and compare with al-Dhahabī, al-Mukhtār 339 (lines 1-2: "lā takūn sabab halāk al-Muslimina") and Tärīkh ii, 45 (lines 15-6: "Iā takun sabab halāk al-Muslimina"). See also al-Jazarī, Ta’īkh i, 194 (line 16: "ḍarabahu alf wa-mia miqra'a"-absence of accusative alif), and compare with al-Dhahabī, al-Mukhtār 363 (line 10: "darabahu alf wa-mia miqra'a") and Ta'rīkh iii, 200 (line 17: "darabahu alfa wa-mi'a miqra'a").

229 Subordinate asyndetic clause comes after lā shakka; and see Blau, Handbook $5^{2}$ (no. 128); Haarmann, Kanz 37.

230 Absence of the accusative alif (here in the case of ism anna); and see Blau, Handbook 44 (no. 74); Zetterstéen, Beiträge 2 . 


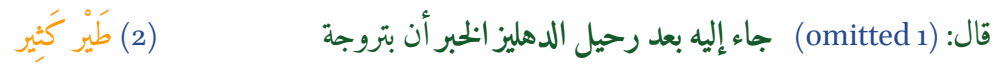

$$
\begin{aligned}
& \text { قال: (omitted 1) لما رحل الدهليز والعسكر جاء الخبر إلى السلطان أن بتروجة (2) طَيرًا كَثِيًا }
\end{aligned}
$$

$$
\begin{aligned}
& \text { فقال: (3) إِمْشَي } 231 \text { بنا حتى نسبق الخاصكية }
\end{aligned}
$$

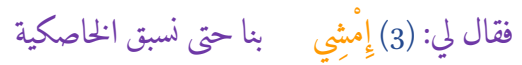

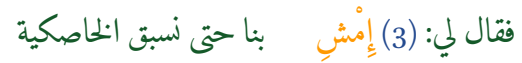

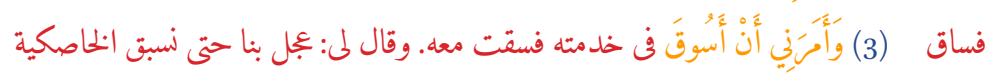

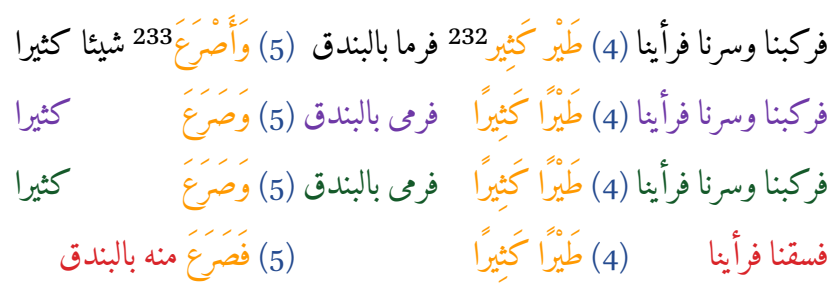

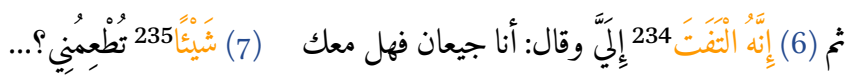

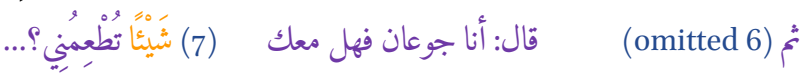

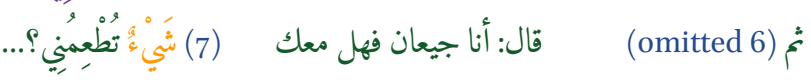

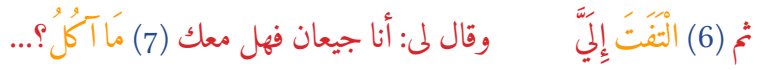

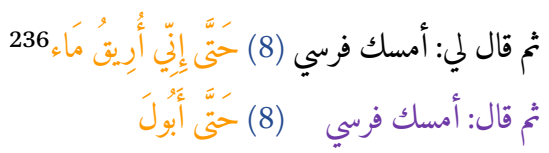

231 Long vowel in a final closed syllable (here in the imperative); and see Blau, Handbook 30 (no. 6); Zetterstéen, Beiträge 28; Haarmann, Kanz 36.

232 Absence of the accusative alif (here in the case of a direct object).

233 Usage of the fourth verbal theme instead of the first verbal theme; and see Blau, Handbook 38 (no. 40); Zetterstéen, Beiträge 2.

234 Superfluous repetition of pronouns; and see Haarmann, Kanz 36.

235 Accusative alif in a noun in singular form that should have been in the nominative according to the rules of standard Arabic; and see Zetterstéen, Beiträge 19; Blau, Handbook 44 (no. 74).

236 Superfluous usage of inna and repetition of a pronoun. In addition, the expression arāqa $m \bar{a}$ in the meaning of "urinated" is apparently "post-classical," see Dozy, Takmilat v, 253. 


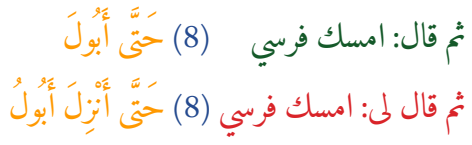

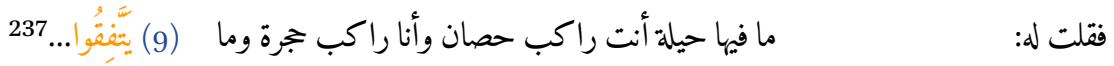

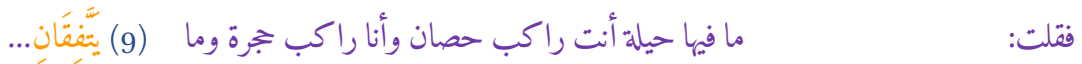

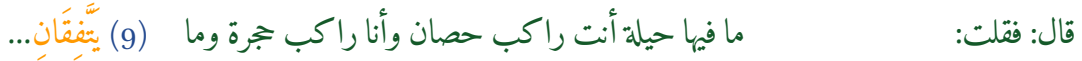

$$
\begin{aligned}
& \text { وكنت كثير البسط معه فقلت: ما فيها حيلة السلطان راكب حصان وأنا راكب حجر وما (9) يتَّفَّان.... }
\end{aligned}
$$

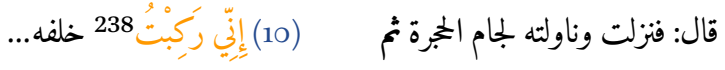

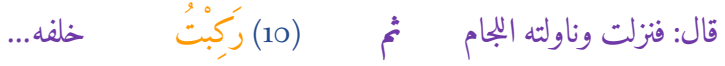

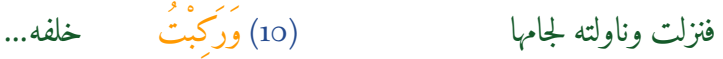

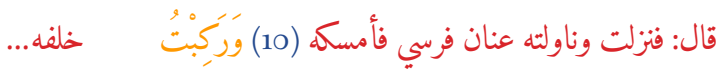

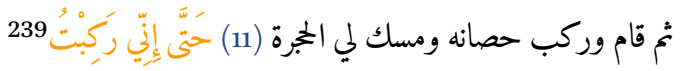

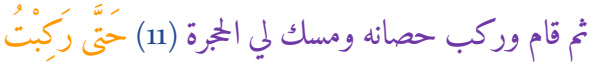

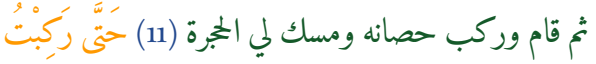

$$
\begin{aligned}
& \text { تمَ قام وركب حصانه ومسك فرسي (11) حَتَّى رَكِبْتُ } \\
& \text { فبينما أنا وهو نتحدث وإذا بغبار عظيم قد ثار وهو (12) جَاي } 240 \text { إلي نحونا }
\end{aligned}
$$

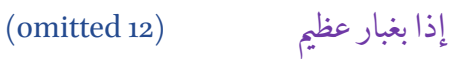

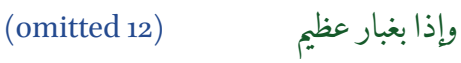

$$
\begin{aligned}
& \text { فبينما أنا وهو نتحدث وإذا بغبار عظيم قد ثار نحونا (omitted 12) }
\end{aligned}
$$

237 Employment of the plural instaed of the dual; see Blau, Handbook 42 (no. 59). Also note that the verb in the indicative terminates without the ending $n$; see ibid. 45 (no. 77 ).

238 Superfluous usage of inna and repetition of a pronoun.

239 Superfluous usage of inna and repetition of a pronoun.

240 While the nonstandard usage in this case is perhaps related to orthography, it seems to reflect the pronunciation of the word in the spoken language (the $y \bar{a}$ 'represents a glide); and see Bauden, Maqriziana VIII 33. 


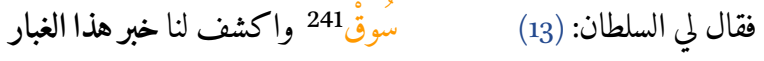

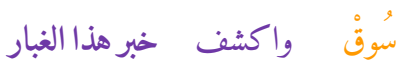

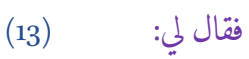

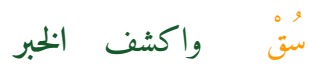

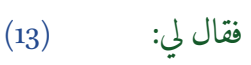

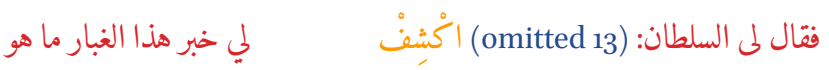

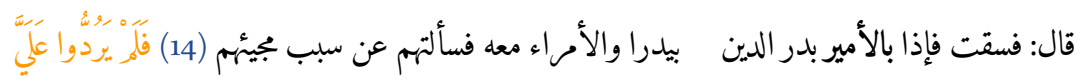

$$
\begin{aligned}
& \text { جَوَاب 242 ولا التفتوا على كلامي }
\end{aligned}
$$

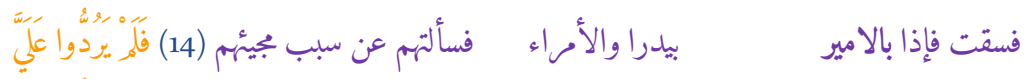

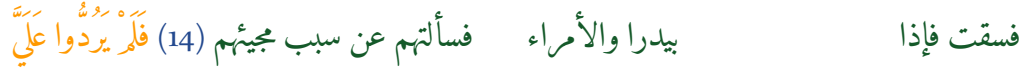

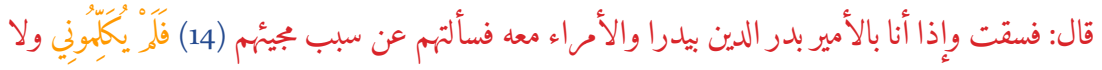

$$
\begin{aligned}
& \text { التفتواء إلمّ }
\end{aligned}
$$

$$
\text { وساقوا على حالهم حتى قربوا من السلطان فكان أول من ابتدره بيدرا بالضربة }
$$

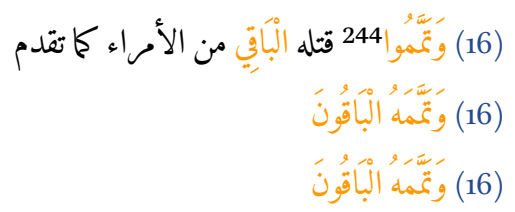

241 Long vowel in a final closed syllable (here in the imperative).

242 Absence of the accusative alif (here in the case of a direct object).

243 Absence of a conjunction; see Zetterstéen, Beiträge 32; Haarmann, Kanz 37.

244 The verb preceding a subject, which designates several persons, stands in the plural (however, the subject itself appears in the singular form); see Blau, Handbook 45 (no. 79); Zetterstéen, Beiträge 31 . 


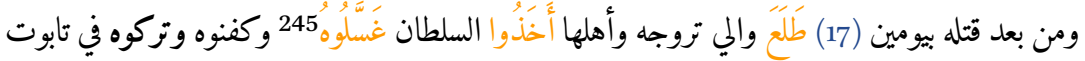

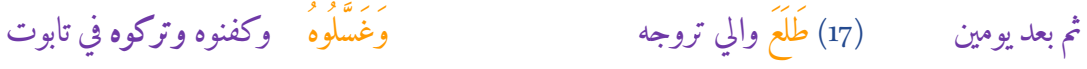

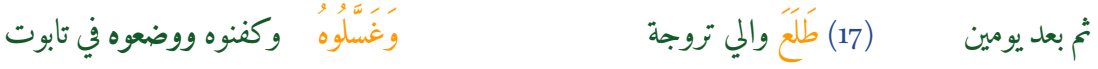

\section{Appendix C: Standardization of al-Shujāīi by Ibn Qāḍī Shuhba}

The text in black is al-Shujā̄ì, and the text in green is Ibn Qāḍi Shuhba. ${ }^{246}$ It is just a small part of a much larger report (about three pages) quoted from alShujā̄î by Ibn Qāḍī Shuhba and standardized systematically. ${ }^{247}$ The instances of nonstandard usages of Arabic and its standardization are marked in orange color and preceded by blue numerals in brackets. I have reproduced the orthography of the printed editions, and orthographical deviations from standard Arabic are ignored. Only the relevant parts are vocalized, and the text is not translated. I have only made brief comments in footnotes on the nonstandard usages.

$$
\begin{aligned}
& \text { وكان (1) هi|l248 صلعان شير بن جوبان (2) حاضر } 249 \\
& \text { وكان (omitted 1) صلغان شير ابن جوبان (2) حَاضرًا }
\end{aligned}
$$

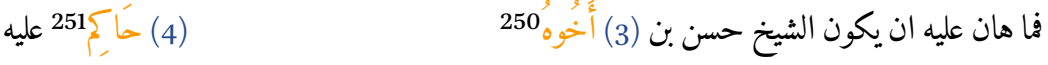

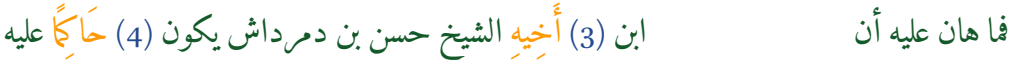

\footnotetext{
245 Absence of conjunctions.

246 Ibn Qāḍī Shuhba, Tảrīkh ii, 131 (line 20)-132 (line 1); al-Shujā̄î̀, Ta’rīkh 100 (lines 8-11).

247 Ibn Qāḍī Shuhba, Tảrīkh ii, 130 (line 5)-132 (line 16); al-Shujāî̀, Tảrīkh 98 (line 12)-101 (line 12). There are a few dozen cases of standardization in the report. In one case, Ibn Qāḍī Shuhba reproduces the wording of al-Shujāīi and fails to standardize it, see Ibn Qāḍi Shuhba, Ta'rīkh ii, 132 (lines 5-6); al-Shujāīī, Ta'rīkh 100 (lines 17-8). It is clearly due to lack of attention. For other examples of standardization, see Ibn Qāḍi Shuhba, Tảīkh ii, 159 (lines 2-17); al-Shujāīī, Ta’rīkh 122 (line 16)-123 (line 16). Apparently, in one case Ibn Qāọī Shuhba reproduces the wording of al-Shujāī and fails to standardize, see Ibn Qāḍī Shuhba, Ta'rīkh ii, 159 (line 14); al-Shujāīī, Ta'rīkh 122 (line 10).

248 The demonstrative pronoun precedes a noun that is not determined by the definite article; see Blau, Emergence 112.

249 Absence of the accusative alif (here in the case of khabar kāna); and see Blau, Handbook 44 (no. 74); Zetterstéen, Beiträge 20.

250 On $a k h \bar{u}$ instead of $a k h \overline{\text {, }}$ see Zetterstéen, Beiträge 22; Brinner, Chronicle, xxiii.

251 Absence of the accusative alif (here in the case of khabar kāna).
} 


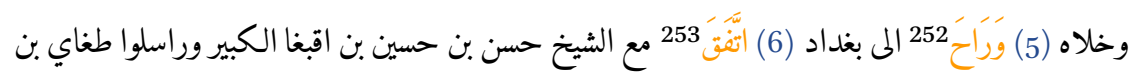

$$
\begin{aligned}
& \text { سوتاي }
\end{aligned}
$$

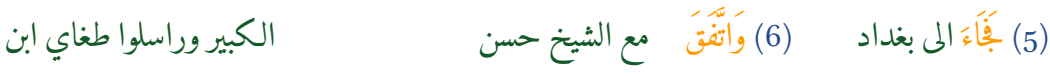

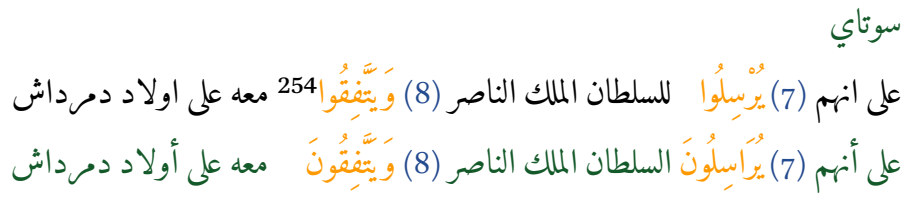

\section{Bibliography}

\section{Primary Sources}

al-'Abbāsī, Nuzhat al-mālik wa-l-mamlūk fı̈ mukhtașar sīrat man walìya Miṣr min almulūk, ed. 'U.'A. al-S. Tadmurī, Șaydā and Beirut 2003.

al-'Aynī, 'Iqd al-jumān fì ta'rīkh ahl al-zamān, ed. 'A. al-R. al-Ṭantāwī al-Qarmūț, Cairo 1989 .

al-'Aynī, al-Sulțān Barqūq mu'assis Dawlat al-Mamālīk al-Jarākisa 1382-1398 Mīlādī/784-

8о1 Hïrī: Min khilāl makhțūt Iqd al-jumān fì ta'rīkh ahl al-zamān li-Badr al-Dīn alAynī, ed. İ.'U. Shukrī, Cairo 2002.

al-'Aynī, Iqd al-jumān fì ta'rīkh ahl al-zamān, ed. M.M. Amīn, 5 vols., Cairo 2009-10.

al-Biqā̄ì̄, Ižnār al-'aṣr li-asrār ahl al-'aṣr Ta’rīkh al-Biqā̄ī, ed. M.S. al-'Awfī, 3 vols., Riyadh 1992-3.

al-Birzālī, al-Muqtafí 'alā Kitāb al-Rawḍatayn al-ma'rūf bi-Ta’rīkh al-Birzālī, ed. 'U.'A. al-

S. Tadmurī, 4 vols., Beirut 2006.

al-Dhahabī, al-Mukhtār min Tảrīkh Ibn al-Jazarī al-musammā Hawādith al-zamān wa-

anbā̉ihi wa-wafayāt al-akābir wa-l-a yān min abnā̉ihi, ed. K.'A.M.K. al-Manshadāwī, Beirut 1988.

al-Dhahabī, Ta’rīkh al-Islām wa-wafayāt al-mashāhīr wa-l-a'lām, ed. 'U.'A. al-S. Tadmurī,

53 vols., Beirut 1989-2004.

al-Dhahabī, Duwal al-Islām, eds. H..I. Marwa and M. al-Arnā’ūt, 2 vols., Beirut 1999.

al-Dimashqī, 'Uqūd al-jumān fì manāqib al-imām al-a'zam Abì Hanīfa al-Nu'mān, ed.

M.M.'A. al-Q. al-Afghānī, Jadda 1979.

al-Fākhirī, Tä̀rīkh al-Fākhirī, ed. 'U.'A. Tadmurī, Beirut 2010.

252 The non-classical verb răha in the meaning of "went," see Haarmann, Kanz 37.

253 Absence of a conjunction; see Zetterstéen, Beiträge 32; Haarmann, Kanz 37.

254 Nos. 7-8: verbs in the indicative that terminate without the ending $n$; see Blau, Handbook 45 (no. 77); Brinner, Chronicle, xxiv; Zetterstéen, Beiträge 31; Haarmann, Kanz 36. 
Ibn Abī al-Wafā' al-Qurashī, al-Jawāhir al-muḍ̂̉a fì țabaqāt al-Hanafìya, ed. 'A. al-F.M. al-Hulw, 2 vols., Cairo 1978.

Ibn al-Dawādārī, Kanz al-durar wa-jāmi‘ al-ghurar, 9 vols., Cairo 196o-92.

Ibn Duqmāq, al-Nafḥa al-miskiyya fì l-Dawla al-Turkiyya: Min Kitāb al-Jawhar al-thamīn fì siyar al-khulafä's wa-l-mulūk wa-l-salāțīn, ed. 'U.'A. al-S. Tadmurī, Beirut and Șaydā 1999.

Ibn Duqmāq, Nuzhat al-anāmfitta’rīkh al-Islām (628 H/1230 M-659 H/1261 M), ed. S. Ṭabbāra, Beirut and Șaydā 1999.

Ibn Faḍl Allāh al-'Umarī, Masālik al-abșār fi mamālik al-amșār: Qabāil al-'Arab fì lqarnayn al-sābic wa-l-thāmin al-hïrīyayn, ed. D. Krawulsky, Beirut 1985.

Ibn al-Furāt, Ta’rīkh al-duwalwa-l-mulūk, eds. Q. Zurayk and N. 'Izz al-Dīn, vol. 9, Beirut 1936-8.

Ibn Ḥajar, al-Durar al-kāmina fì a'yān al-mi’a al-thāmina, ed. S. al-Karnūkī, 4 vols., Hayderabad 1929-31.

Ibn Ḥajar, Inbä’’ al-ghumr bi-anbā’ al-umr, ed. H.. Habashī, 4 vols., Cairo 1969-98.

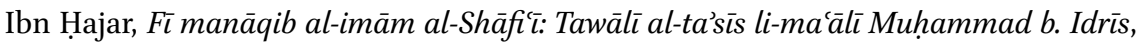
ed. A. al-F.'A. al-Qāẹī, Beirut 1986.

Ibn Kathīr, al-Bidāya wa-l-nihāya fì l-ta’rīkh, ed. 'A. Shīrī, 14 vols., Beirut 1988.

Ibn Kathīr, Manāqib al-imām al-Shāfī̄, ed. K.I.M. Khāțir, Riyadh 1992.

Ibn Kathīr, Țabaqāt al-Shāfi ciyya, ed. 'A. al-Ḥ. Manșūr, 2 vols., Beirut 2004.

Ibn Qāḍī Shuhba, Ta’rīkh Ibn Qāḍ̄ Shuhba, ed. 'A. Darwīsh, 4 vols., Damascus 1977-97.

Ibn Qāḍī Shuhba, Ṭabaqāt al-Shāfíiyya, ed. al-H.'A. al-'A. Khān, 4 vols., Hyderabad 19788 o.

Ibn Qāḍī Shuhba, Kitāb Manāqib al-imām al-Shāfĩ̄ wa-țabaqāt aṣhābihi min Tảrīkh alIslām lil-hāäiz Ab̄̄ Abdallāh al-Dhahabī, ed. 'A. al-'A.F. Harfūsh, Damascus 2003.

Ibn Qudāma al-Maqdisī, Manāqib al-a’imma al-arba'a radiya Allāh 'anhum, ed. S.M. alHarsh, Beirut 1995-6.

Ibn Rajab, al-Dhayl 'alā Tabaqāt al-Hanābila, ed. 'A. al-R. al-'Uthaymin, 5 vols., Riyadh 2005 .

Ibn al-Șayrafī, Inbä’ al-hașr bi-abnā̉ al-'așr, ed. Ḥ. Ḥabashī, Cairo 1970.

Ibn al-Șayrafī, Nuzhat al-nufūs wa-l-abdān fì tawārīkh al-zamān, ed. Ḥ. Ḥabashī, 4 vols., Cairo 1970-94.

Ibn Taghrībirdī, Kitāb al-Nujūm al-zāhira fìmulūkMiṣrwa-l-Qāhira, eds. F.M. Shaltūt et al., 16 vols., Cairo 1929-72.

Ibn Taghrībirdī, al-Manhal al-șāfí wa-l-mustawfā ba'da al-Wāfí, ed. M.M. Amīn, 12 vols., Cairo 1984-2006.

Ibn Ṭūlūn, Mufākahat al-khillān fì ḥawādith al-zamān, ed. M. Muṣțafā, 2 vols., Cairo 1962-4.

Ibn Ṭūlūn, I'lām al-warā bi-man walìy nāiban min al-Atrāk bi-Dimashq al-Sha'm alKubrā, ed. M.A. Dahmān, Damascus 1984. 
Ibn Ṭūlūn, Mufākahat al-khillān fi ḥawādith al-zamān, ed. K. al-Manșūr, Beirut 1998. al-Jazarī, Ta'rīkh hawādith al-zamān wa-anbā’ihi wa-wafayāt al-akābir wa-l-ayān min abnā̉ihi al-ma'rüf bi-Ta'rīkh Ibn al-Jazarī, ed. 'U.'A. al-S. Tadmurī, 3 vols., Șaydā and Beirut 1998.

al-Kardarī, Manāqib al-imām al-a'zam Abì Hanīfa, Hayderabad $19 \circ 3$.

al-Kutubī, Fawāt al-wafayāt, ed. I. 'Abbās, 4 vols., Beirut 1973-4.

al-Malațī, al-Raw ḍ al-bāsim fì hạāādith al-'umur wa-l-tarājim, ed. 'U.'A. al-S. Tadmurī, 4 vols., Beirut 2014.

al-Maqdisī, Kitāb Duwal al-Islām al-sharīfa al-bahiyya wa-dhikr mā zahara lī min hikam Allāh al-khafiyya fi jalb țāiffat al-Atrāk ilā al-Diyār al-Miṣriyya, eds. Ṣ. Labīb and U. Haarmann, Beirut 1997.

al-Maqdisī, Ta’rīkh al-Malik al-AshrafQāytbāy, ed. 'U.'A. al-S. Tadmurī, Beirut and Șaydā 2003.

al-Maqrīzì, Kitāb al-Khabar 'an al-bashar fì ansāb al-'Arab wa-nasab sayyid al-bashar, ed. K.A. al-Suwaydī and 'Ā. 'Abd al-Ghan̄̄, 8 vols., Beirut 2013.

al-Maqrīzī, Kitāb al-Sulūk li-márifat duwal al-mulūk, ed. M.M. Ziyāda and S.'A. al-F. 'Āshūr, 4 vols., Cairo 1934-73.

al-Maqrīzì, Kitāb al-Mawā'iz wa-l-itibār bi-dhikr al-khițaț wa-l-āthār, ed. K. al-Manșūr, 4 vols., Beirut 1998.

al-Maqrīzī, Rasā̉il al-Maqrīzī, eds. R. al-Badrī and A.M. Qāsim, Cairo 1998.

al-Nuwayrī, Nihāyat al-arab fı funūn al-adab, eds. I. Shams al-Dīn et al., 33 vols., Beirut 2004.

al-Nuwayrī al-Iskandarānī, al-Ilmām bi-l-il'ām fìmā jarat bi-hi al-ạ̣kām wa-l-umūr almaqdiyya fíwaq'at al-Iskandariyya, eds. E. Combe and A.S. Atiya, 7 vols., Hyderabad 1968-76.

al-Qalqashandī, Qalāìd al-jumān fì l-tárîf bi-qabāil 'Arab al-zamān, ed. I. al-Abyārī, Cairo 1963 .

al-Qalqashandī, Nihāyat al-arab fìma'rifat ansāb al-'Arab, ed. I. al-Abyārī, Beirut 198o. Qarațāy al-Khaznadārī, Ta’rīkh majmū' al-nawādir mimmā jarā lil-awāil wa-l-awākhir, ed. 'U.'A. al-S. Tadmurī, Șaydā and Beirut 2005.

al-Șafadī, al-Wāfı bi-l-wafayāt, eds. H. Ritter et al., 3o vols., Wiesbaden 1962-2004. al-Ṣafadī, A'yānn al-'aṣr wa-a'wā̄n al-nașr, ed. 'A. Abū Zayd, 6 vols., Beirut 1998. al-Sakhāwī, al-Ḍaw' al-lāmi 'li-ahl al-qarn al-tāsi', 12 vols., Beirut 1992. al-Sakhāwī, Wajīz al-kalām fì l-dhayl 'alā Duwal al-Islām, ed. B.'A. Ma'rūf, 'I.F. alḤarastānī and A. al-Khuțaymī, 4 vols., Beirut 1995.

al-Shujā̄īi, Tảīkh al-Malik al-Nāṣir Muhammad b. Qalāwūn al-Ṣāliḥī wa-awlādihi, ed.

B. Schäfer, Wiesbaden 1977.

al-Subkī, Ṭabaqāt al-Shāfíiyya al-kubrā, eds. M.M. al-Ṭanāḥī and 'A. al-F.M. al-Ḥulū, 10 vols., Cairo 1964.

al-Yūsufî, Nuzhat al-nāzirir fì sìrat al-Malik al-Nāṣir, ed. A. Huṭayț, Beirut 1986. 


\section{Secondary Sources}

'Abd al-Rahīm, Y., Mawsū'at al-'Āmmiyya al-Sūriyya: Kurrāsa lughawiyya naqdiyya fì ltafșịn wa-l-ta’șill wa-l-muwallad wa-l-dakhïl, 3 vols., Damascus 2012.

Ali, K., Imam Shafi i: Scholar and saint, Oxford 2011.

'Āṭif, M. et al., Adabiyyāt al-lugha al-'Arabiyya, Cairo 2015.

al-Bābānī, I., Hadiyyat al-'ārifìn asmā' al-mu'allifin wa-āthār al-muṣannifin, 2 vols., Istanbul 1951.

Badawi, E., and M. Hinds, Dictionary of Egyptian Arabic: Arabic-English, Beirut 1986.

Bauden, F., Maqriziana II: Discovery of an autograph manuscript of al-Maqrīzī: Towards a better understanding of his working method: Analysis, in MSR 12/1 (2008), 51-118.

Bauden, F., Maqriziana viıI: Quelques remarques sur l' orthographe d' al-Maqrīzī ( $\mathrm{m}$. 845/1442) à partir de son carnet de notes: peut-on parler de moyen arabe?, in J. Lentin and J. Grand'Henry (eds.), Moyen arabe et variétés mixtes de l'arabe à travers l'histoire: Actes du Premier Colloque International, Louvain-la-Neuve 20o8, 2138.

Bauden, F., Like father, like son: The chancery manual (Qalāid al-jumān) of alQalqashandī's son and its value for the study of Mamluk diplomatics (ninth/fifteenth century), in Eurasian studies 6 (2013), 181-228.

Bauer, Th., Literarische Anthologien der Mamlūkenzeit, in S. Conermann and A. PistorHatam (eds.), Die Mamlūken: Studien zu ihrer Geschichte und Kultur. Zum Gedenken an Ulrich Haarmann (1942-1999), Hamburg 2003, 71-122.

Bauer, Th., Review of Nuzhat al-anām fi ta'rīkh al-Islām (628 H/123o M-659 H/1261 M), ed. S. Ṭabbāra, Beirut and Ṣaydā 1999, in MSR 7/1 (2003), 257-62.

Bauer, Th., Mamluk literature: Misunderstandings and new approaches, in $M S R$ 9/2 (2005), 105-32.

Bauer, Th., In search of "post-classical literature": A review article, in MSR 11/2 (2007), 137-67.

Bauer, Th., Mamluk literature as a means of communication, in S. Conermann (ed.), Ubi Sumus? Quo Vademus? Mamluk studies — State of the art, Goettingen and Bonn 2013, 23-56.

Blau, J., The emergence and linguistic background of Judaeo-Arabic: A study of the origins of Middle Arabic, Jerusalem 1981.

Blau, J., The state of research in the field of the linguistic study of Middle Arabic, in Arabica 28 2/3 (1981), 187-203.

Blau, J., A handbook of Early Middle Arabic, Jerusalem 2002.

Blau, J., A dictionary of mediaeval Judaeo-Arabic texts [in Hebrew], Jerusalem 2006.

Bora, F., Mamluk historian's holograph. Messages from a musawwada of ta'rīkh, in Journal of Islamic manuscripts 3/2 (2012), 119-53.

Brinner, W.M. (ed.), A chronicle of Damascus 1389-1397, vol. 1, Berkeley and Los Angeles 1963. 
Brockelmann, C., History of the Arabic written tradition: Volume 2, trans. J. Lameer, Leiden 2016.

Burton, J. (ed.), Abū 'Ubaid al-Qāsim b. Sallām's K. al-Nāsikh wa-l-mansūkh, Suffolk 1987.

Cahen, C., Ibn al-Furāt, Nāṣir al-Dīn Muhammad b. 'Abd al-Rahīim b. 'Alī al-Mișrī alHanafì, in $E I^{2}$, iii, $768-9$.

Conermann, S., Ibn Ṭūlūn (d. 955/1548): Life and works, in MSR 8/1 (2004), 115-39.

Conermann, S., and T. Seidensticker, Some remarks on Ibn Țawq's (d. 915/1509) journal Al-Talìq, vol. 1 (885/148o to 89o/1485), in MSR 11/2 (2007), 121-35.

Dozy, R.P.A., Takmilat al-ma'äjim al-'Arabiyya, 10 vols., trans. M.S. al-Nu'aymī and J. alKhayyāț, Baghdad 1979-20oo.

Elbendary, A., Crowds and sultans: Urban protests in late medieval Egypt and Syria, Cairo 2015 .

Fück, J.W., 'Arabiyya: Middle Arabic, in $E I^{2}$, i, 569-71.

Ghersetti, A., The language(s) of the Arabs in al-Maqrīzì's al-Khabar 'an al-bashar, in QSA 9 (2014), 145-6o.

Guo, L., Mamluk historiographic studies: The state of the art, in MSR 1 (1997), 15-43.

Guo, L., Introduction: The DhaylMir'ātal-zamān in modern scholarship, in L. Guo (ed.), Early Mamluk Syrian historiography: Al-Yunīnìs Dhayl Mir'āt al-zamān, vol. 1, Leiden 1998.

Guo, L., al-Biqā̄î's chronicle: A fifteenth century learned man's reflection on his time and world, in H. Kennedy (ed.), The historiography of Islamic Egypt (c. 950-1800), Leiden 2001, 121-48.

Guo, L., Commerce, culture, and community in a Red Sea port in the thirteenth century: The Arabic documents from Quseir, Leiden 2004.

Guo, L., Tales of a medieval Cairene harem: Domestic life in al-Biqāī's autobiographical chronicle, in MSR 9/1 (2005), 101-21.

Guo, L., History writing, in R. Irwin (ed.), The new Cambridge history of Islam: Islamic cultures and societies to the end of the eighteenth century, vol. 4, Cambridge 2010, $444-57$.

Guo, L., Songs, poetry, and storytelling: Ibn Taghrī Birdī on the Yalbughā affair, in Y. BenBassat (ed.), Developing perspectives in Mamluk history: Essays in honor of Amalia Levanoni, Leiden 2017, 189-200.

Haarmann, U., Quellenstudien zur frühen Mamlukenzeit, Freiburg 1969.

Haarmann, U., Auflösung und Bewahrung der klassischen Formen arabischer Geschichtsschreibung in der Zeit der Mamluken, in ZDMG 121 (1971), 46-6o.

Haarmann, U. (ed.), Kanz al-durarwa-jāmi al-ghurar, vol. 8, Cairo 1971.

Haarmann, U., Arabic in speech, Turkish in lineage: Mamluks and their sons in the intellectual life of fourteenth-century Egypt and Syria, in JSS 33/1 (1988), 81-114.

Haarmann, U., Rather the injustice of the Turks than the righteousness of the Arabs: 
Changing ' $u l a m \bar{a}$ ' attitudes towards Mamluk rule in the late fifteenth century, in $S I$ 68 (1988), 61-77.

Haarmann, U., Review of Weltgeschichte und Weltbeschreibung im Mittelalterlichen Islam, by B. Radtke, in JAOS 115/1 (1995), 133-5.

Haarmann, U., Review of Twilight of majesty: The reigns of Mamlūk sultans Al-Ashraf Qāytbāy and Qānșūh al-Ghawrī in Egypt, by C.F. Petry, in IJMES 29/4 (1997), 6358.

Haarmann, U., Joseph's law-The careers and activities of Mamluk descendants before the Ottoman conquest of Egypt, in Th. Philipp and U. Haarmann (eds.), The Mamluks in Egyptian politics and society, Cambridge 1998, 55-84.

Haarmann, U., al-Maqrīzī, the master, and Abū Ḥāmid al-Qudsī, the disciple-Whose historical writing can claim more topicality and modernity?, in H. Kennedy (ed.), The historiography of Islamic Egypt (c. 950-1800), Leiden 2001, 149-65.

Hanna, N., The chronicles of Ottoman Egypt: History or entertainment?, in H. Kennedy (ed.), The historiography of Islamic Egypt (c. 950-180o), Leiden 2001, 237-50.

Hartmann, R. (ed.), Das Tübinger Fragment der Chronik des Ibn Ṭūtūn, Berlin 1926.

Havemann, A., The chronicle of Ibn Iyās as a source for social and cultural history from below, in M. Haddad et al. (eds.), Towards a cultural history of the Mamluk era, Beirut 2010, 87-100.

Herzog, Th., Mamluk (popular) culture, in S. Conermann (ed.), Ubi Sumus? Quo Vademus? Mamluk studies - State of the art, Goettingen and Bonn 2013, 131-58.

Hirschler, K., Islam: The Arabic and Persian traditions, eleventh-fifteenth centuries, in A. Feldherr et al. (eds.), The Oxford history of historical writing: 400-1400, vol. 2, Oxford 2012, 267-86.

Hirschler, K., The written word in the Medieval Arabic Lands: A social and cultural history of reading practices, Edinburgh 2012.

Ībish, A., Ta’rīkh al-Sha'm fı̀ mațla' al-'ahd al-'Uthmānī 926-951 H/1520-1544 M istinādan ilā makhțūtāt nādira fı Maktabat al-Dawla (Staatsbibliothek) wa-i'ādat jam al-ṣafahāàt al-ḍā'ía min Kitāb Mufākahat al-khillān fi hawādith al-zamān li-Ibn Ṭūlūn al-Șāliḥi al-Dimashqī, Abu Dhabi 2010.

Irwin, R., Mamluk history and historians, in R. Allen and D.S. Richards, Arabic literature in the post-classical period, Cambridge 2006, 159-70.

Jaques, R.K., Authority, conflict, and the transmission of diversity in medieval Islamic law, Leiden 2006.

Jaques, R.K., The other Rabī': Biographical traditions and the development of early Shāfíī authority, in Islamic law and society 14/2 (2007), 143-79.

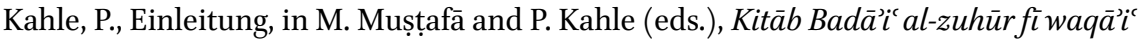
al-duhūr, vol. 4, Leipzig 1931, 1-29.

Krenkow, F., and D.P. Little, al-Ṣafadī, al-Ḥasan b. Abī Muḥammad 'Abdallāḥ alHāshimī, in $E I^{2}$, xiii, 759 . 
Landau-Tasseron, E., The "cyclical reform": A study of the mujaddid tradition, in $S I 70$ (1989), 79-117.

Lentin, J., The Levant, in C. Holes (ed.), Arabic historical dialectology: Linguistic and sociolinguistic approaches, Oxford 2018, 170-205.

Levanoni, A., Who were the "salt of the earth" in fifteenth-century Egypt?, in MSR 14 (2010), 63-83.

Levanoni, A., A supplementary source for the study of Mamluk social history: The taqārīz, in Arabica 6o/1-2 (2013), 146-77.

Little, D.P., An introduction to Mamlūk historiography: An analysis of Arabic annalistic and biographical sources for the reign of al-Malik an-Nāṣir Muhammad b. Qalāūun, Wiesbaden 1970.

Little, D.P., An analysis of the relationship between four Mamluk chronicles for 737-45, in Jss 19 (1974), 252-68.

Little, D.P., The recovery of a lost source for Baḥ̂̄ Mamlūk history: Al-Yūsufî’s Nuzhat al-nāzir fì sìrat al-Malik al-Nāṣir, in JAOs 94 (1974), 42-54.

Little, D.P., Historiography of the Ayyūbid and Mamlūk epochs, in C.F. Petry (ed.), The Cambridge history of Egypt: Islamic Egypt, 640-1517, vol. 1, Cambridge and New York 1998, 412-44.

Lowry, J.E., Some preliminary observations on al-Shāfīì and later uṣūl al-figh: The case of the term bayān, in Arabica 55/5 (2008), 505-27.

Massoud, S.G., The chronicles and annalistic sources of the early Mamluk Circassian period, Leiden and Boston 2007.

Mauder, C., Gelehrte Krieger: Die Mamluken als Träger arabischsprachiger Bildung nach al-Ṣafadī, al-Maqrīzì und weiteren Quellen, Hildesheim 2012.

Muhannā, M.N., Ādāb al-mulūk: Katabahu al-mamlūk Bardi Bak min Ṭabaqat alMustajadda al-Malikī al-Ashrafī, in AI 22 (1986), 1-9.

Ökzan, H., The drug zajals in Ibrāhīm al-Mi'mār's Dīwān, in MSR 17 (2013), 212-48.

Parry, V.J., Review of Quellenstudien zur frühen Mamlukenzeit, by U. Haarmann, in BSOAS 35 (1972), 148-9.

Petry, C.F., The civilian elite of Cairo in the later middle ages, Princeton 1981.

Petry, C.F., Scholastic stasis in medieval Islam reconsidered: Mamluk patronage in Cairo, in Poetics Today 14/2 (1993), 323-48.

Petry, C.F., Protectors or praetorians? The last Mamlük sultans and Egypt's waning as a great power, Albany 1994.

Rabbat, N.O., Representing the Mamluks in Mamluk historical writing, in H. Kennedy (ed.), The historiography of Islamic Egypt (c. 950-180o), Leiden 2001, 59-75.

Rizq Salīm, M., al-Adab al-'Arabì wa-ta'rīkhuhu fì 'așr al-Mamālīk wa-l-'Uthmāniyyìna wa-l-'așr al-hadith, Cairo 1957.

Roemer, H.R. (ed.), Kanz al-durar wa-jāmi‘ al-ghurar, vol. 9, Cairo 196o.

Schäfer, B. (ed.), Beiträge zur mamlukischen Historiographie nach dem Tode al-Malik anNāṣirs, mit einer Teiledition der Chronik Šams ad-Dīn as-Šuğăàss, Freiburg 1971. 
Schäfer, B. (ed.), Die Chronik aš-Šuğă $\iota^{\prime} s$, Wiesbaden 1985.

Taymūr, A., Mu'jam Taymūr al-kabìr fì l-alfāz al-'āmmiyya, 6 vols., Cairo 2002.

Tritton, A.S., Review of The chronicle of Ibn Tulun, ed. by M. Mostafa, Cairo 1962, in JRAS 96/1 (1964), 54-5.

Vrolijk, A., Bringing a laugh to a scowling face: A study and critical edition of the Nuzhat al-nufūs wa-muḍik al-'abūs by 'Al̄ Ibn Sūdūn al-Bashbughāwì (Cairo 810/1407Damascus 868/1464), Leiden 1998.

Wollina, T., Ibn Ṭawq's Ta lìq: An ego document for Mamlūk studies, in S. Conermann (ed.), Ubi Sumus? Quo Vademus? Mamluk studies - State of the art, Goettingen and Bonn 2013, 337-62.

Yosef, K., Cross-boundary hatred: (Changing) attitudes towards Mongol and "Christian" mamlūks in the Mamluk Sultanate, in R. Amitai and S. Conermann (eds.), The Mamluk Sultanate from the perspective of regional and world history: Economic, social and cultural development in an era of increasing international interaction and competition, Goettingen and Bonn 2019, 149-214.

al-Zarkalī, Kh., al-A'lām: Qāmūs tarājim li-ashhar al-rijāl wa-l-nisā' min al-'Arab wa-lMusta'ribin wa-l-Mustashriqin, 8 vols., Beirut 2002.

Zetterstéen, K.W. (ed.), Beiträge zur Geschichte der Mamlūkensultane in den Jahren 69o741 der Higra nach arabischen Handschriften, Leiden 1919. 